\title{
BALTŲ KARYBOS VIDURINIAME GELEŽIES AMŽIUJE (V-VIII A.) BRUOŽAI
}

\author{
Dr. Manvydas Vitkūnas \\ Generolo Jono Žemaičio Lietuvos karo akademija
}

\section{IVADAS}

Tęsiame baltų karybos raidai skirtų mokslinių apžvalginių straipsnių ciklą, nuo 2003 m. spausdinamą tęstiniame leidinyje „Karo archyvas“" ${ }^{\text {. Jo }}$ tikslas - aptarti baltų karybos bruožus remiantis archeologinių tyrimų (pirmiausia dabartineje Lietuvos teritorijoje) duomenimis.

Tarsi istorinè įžanga buvo autoriaus ankstesnè publikacija apie Dniepro baltų karybą ${ }^{2}$ Šiame straipsnyje tęsiama pradèta nagrinèti tema ir aptariami baltų genčių (išskyrus Dniepro baltus) karybos viduriniame geležies amžiuje (V-VIII a.) bruožai.

Daug informacijos apie baltų karybą aptariamuoju laikotarpiu suteikia archeologinių tyrimų medžiaga, o štai rašytiniai V-VIII a. šaltiniai yra itin fragmentiški, todèl straipsnyje pirmiausia remiamasi archeolo-

\footnotetext{
1 Michelbertas M., Vitkūnas M. Baltų karybos senajame geležies amžiuje (I-IV a.) bruožai // Karo archyvas. T. XVIII. Vilnius, 2003, p. 8-64; Šatavičius E. Akmens amžiaus karyba Lietuvoje // Karo archyvas. T. XIX. Vilnius, 2004, p. 6-29; Merkevičius A. Karyba Lietuvos teritorijoje žalvario amžiuje // Karo archyvas. T. XX. Vilnius, 2005, p. 8-49; Vitkūnas M. Baltų karybos ankstyvajame geležies amžiuje (V-I a. pr. Kr.) bruožai // Karo archyvas. T. XXII. Vilnius, 2007, p. 5-33; Vitkūnas M. Baltų karyba viduriniame ir vèlyvajame geležies amžiuje. Dniepro baltai // Karo archyvas. T. XXIV. Vilnius, 2009, p. 4-34.

2 Vitkūnas M. Baltų karyba viduriniame ir vèlyvajame geležies amžiuje. Dniepro baltai // Karo archyvas. T. XXIV. Vilnius, 2009, p. 4-34. Tąkart buvo užsibrèžta (žr. min. str., p. 5) paskelbti tris straipsnius apie baltų karybą viduriniame ir vèlyvajame geležies amžiuje laikantis teritorinio principo (po vieną publikaciją Dniepro, rytų ir vakarų baltų karybos problematikai). Sumanymą kiek patikslinus, užuot šią temą nagrinèjus regioniniu principu, nutarta centrinio ir vakarinio baltų arealų karybos raidą aptarti chronologiškai - geležies amžiaus etapais. Šiame straipsnyje nagrinejjami baltų karybos viduriniame geležies amžiuje ypatumai, vėlyvajam geležies amžiui bus skirtos kitos publikacijos.
} 
ginių tyrimų duomenimis. Jie gana patikimai leidžia rekonstruoti baltų genčių ginkluotę, suteikia daug žinių apie to meto fortifikaciją, tačiau gali būti tik netiesioginiai ịrodymai aptariant tokius svarbius karybos elementus kaip strategija ir taktika. Nagrinejant to paties laikotarpio kaimyninių etninių grupių (slavų, germanų) karybos raidą galima disponuoti nepalyginti gausesniais rašytiniais šaltiniais, kuriuose neretai netgi gana išsamiai aprašoma kovos rikiuotè, konkrečios kautynès, taktiniai sprendimai.

Baltų karybos tyrèjams tenka susidurti su dilema - apskritai apeiti šią temą dèl šaltinių stokos (kas iki šiol daroma) ar rizikuoti imtis netiesioginių šaltinių (kalbančių ne apie baltus, o apie jų kaimynus) analizès ir gretinti su baltų žemių archeologine medžiaga. Šis būdas ne itin patikimas, tačiau, deja, vienintelis, leidžiantis bandyti atsakyti i klausimą: „Kaip kovojo mūsų protèviai?“ I kitus du esminius klausimus: „Kokiais ginklais kovojo?" ir „Kokiuose ịtvirtinimuose gynėsi?“ - jau gana aiškiai atsakyta ịvairių archeologų darbuose.

Šiame straipsnyje dèmesị sutelksime ị keturis baltų karybos viduriniame geležies amžiuje aspektus: ginkluotę, žirgų naudojimo ypatumus, karinès organizacijos raidą ir kovos taktiką. Liks neaptarti šio amžiaus baltų fortifikacijos, gynybinių įtvirtinimų įrengimo, jų gynybos ir šturmavimo klausimai. Šiai temai bus skirtas atskiras straipsnis viename iš būsimų „Karo archyvo“ tomų.

\section{CHRONOLOGIJA}

Vidurinis geležies amžius - geležies amžiaus laikotarpis, dèl kurio chronologijos ne tik Lietuvos, bet ir kaimyninių kraštų archeologai diskutuoja jau kone šimtą metų. I tūkstantmečio po Kristaus laikų Europoje vyko globalūs procesai. Jie turejjo įtakos ir baltų genčių raidai. Todèl neatsitiktinai geležies amžiaus laikotarpiams suteikti ne tik su archeologija (senasis, vidurinis, velyvasis), bet ir su istorinemis to meto aktualijomis susiję pavadinimai. Senasis geležies amžius (I-IV a.) vadinamas ir roméniškuoju (romėnų įtakos), vėlyvasis (VIII (IX, X) - XII a.) - vikingu arba baltu genčių konsolidacijos laikotarpiu.

Tarp senojo ir vèlyvojo išskiriamas vidurinis geležies amžius. Dažniausiai jis vadinamas dar ir tautų kraustymosi laikotarpiu. Ilgą laiką Lie- 
tuvos archeologų buvo ịprasta vidurinị geležies amžių datuoti V-VIII a. Jam sovietmečiu buvo taikomas ir marksistinis klasinès visuomenès formavimosi laikotarpio apibūdinimas ${ }^{3}$. A. Tautavičius pabandè išplèsti vidurinio geležies amžiaus ribas iki IX-X a. sandūros ir taip toliau „nukèlë vèlyvojo geležies amžiaus pradžiąa . Tačiau naujausiuose Lietuvos ir Latvijos archeologų parengtuose darbuose vèl linkstama IX a. priskirti vèlyvajam geležies amžiui ${ }^{5}$.

Naujausiame periodizacijos modelyje, siūlomame Lietuvos istorijos instituto leidžiamos daugiatomès "Lietuvos istorijos" autorių, vidurinis geležies amžius vadinamas tautų kraustymosi ir baltų genčiu sklaidos laikotarpiu ir datuojamas 450-800 m., t. y. nuo Romos imperijos žlugimo iki vikingų judejjimo pradžios. Šis chronologinis skirstymas iš esmès sutampa su dar XX a. pradžioje vokiečių archeologų nustatyta periodizacijos sistema, naudota Rytprūsių archeologiniam paveldui datuoti. Atsižvelgiant ị regioninius ypatumus šiek tiek pakoreguota vidurinio geležies amžiaus (V-VIII a.) periodizacijos sistema taikoma ir Skandinavijos šalyse (Norvegijoje 400-800 m. vadinami tautu kraustymosi ir Merovingu, Švedijoje 400-55 m. - tautu kraustymosi, 550-800 m. - Vendelio, Danijoje 400-800 m. - germaniškuoju laikotarpiu) $)^{6}$.

E. Jovaiša yra sukritikavęs „Lietuvos istorijos“ autorių pasirinktą priešistorès periodizacijos modelị, pagrịsta ne vidiniais baltų visuomenès raidos, o išoriniais veiksniais, ir siūlo pirmiausia atkreipti dèmesị $i$ vidinius baltiškojo pasaulio procesus ir aptariamojo laikotarpio epochas vadinti baltu kultūrų sklaidos (I a.-V a. vid.) ir baltu genčiu isikürimo (V a. antroji pusé-IX a.) laikais?.

Lenkijoje ir Rusijoje vidurinio ir vèlyvojo geležies amžių sąvokos nevartojamos. Laikotarpis nuo Didžiojo tautų kraustymosi laikų iki valsty-

3 Kulikauskas P., Kulikauskienè R., Tautavičius A. Lietuvos archeologijos bruožai. Vilnius, 1961, p. 269.

4 Tautavičius A. Vidurinis geležies amžius Lietuvoje (V-IX a.). Vilnius, 1996.

5 Lietuvos istorija. T. 2. Geležies amžius. Vilnius, 2007; Latvijas senākā vēsture. 9 g. t. pr. Kr.-1200. g. Rìga, 2001.

6 Lietuvos istorija. T. 2. Geležies amžius. Vilnius, 2007; skyrių „Tautų kraustymosi ir baltų genčių sklaidos laikotarpis“ (p. 173-297), parašè I. Vaškevičiūtè.

7 Jovaiša E. Baltiškosios savimonės aspektai proistorès tyrimuose // Istorija. T. 72. Vilnius, 2008, p. 3-9. 
bių susidarymo vadinamas ankstyvaisiais viduramžiais. Lenkijoje kartais kaip atskira epocha dar išskiriamas Didžiojo tautų kraustymosi laikotarpis (IV a. antroji pusé - VI-VII a. riba) ${ }^{8}$. Baltarusijoje geležies amžius skirstomas į ankstyvąji (VII-VI a. pr. Kr. - IV a.) ir vèlyvąji (V-VIII a.)9.

Šiame straipsnyje vidurinis geležies amžius datuojamas V-VIII a. Chronologijos klausimais jame nediskutuojama. Esu tikras, kad savaip teisūs ir savų argumentų rinkiniu yra ginkluoti ir vieno, ir kito vidurinio geležies amžiaus datavimo modelio šalininkai. Šiame tyrimų etape, man atrodo, tinkamas su bendraisiais Europos raidos procesais susijęs periodizacijos modelis, juolab kad kalbama apie išorinių ịtakų ganėtinai stipriai veikiamą gyvenimo sriti - karybą.

\section{BENDRIEJI LAIKOTARPIO BRUOŽAI}

Vidurinis geležies amžius - laikotarpis, chronologiškai ribojamas dviejų globalių procesų - Didžiojo tautų kraustymosi (IV-V a.) ir vikingų ekspansijos pradžios (VIII a. pab.). Abu šie procesai turejjo tiesioginę itaką baltų žemèse vykusiems pokyčiams.

Didysis tautų kraustymasis palietė baltų arealą, ypač jo vakarinę ir pietinę dalị bei visą Dniepro baltų regioną. Manoma, kad V a. ị baltų žemes buvo įsiveržę klajokliai hunai ${ }^{10}$, o VI a. baltai neabejotinai turejjo ryšių su kitais klajokliais - avarais.

Ir su hunais, ir su jiems artimais klajokliais akacirais (akacirus savo kronikoje VI a. mini Jordanas) ${ }^{11}$ bandoma sieti tribriaunius strèlių antgalius, randamus dabartineje Lietuvos teritorijoje. A. Luchtanas sieja šiuos antgalius su hunų, kurie veržèsi iš dabartinès Vengrijos teritorijos,

8 Godłowski K., Kozłowski J. K. Historia starożytna ziem polskich. Warszawa, 1979, p. 19; Lietuvos istorija. T. 2. Geležies amžius. Vilnius, 2007, p. 176.

9 Вяргей В., Егарэйчанка А. Жалезны век // Археалогія і нумізматыка Беларусі. Энцыклапедыя. Мінск, 1993, с. 250-252.

10 Išsamiausias straipsnis apie hunų karinių žygių pėdsakus dabartinèje Lietuvos teritorijoje: Лухтан А. Война V века в Литве // Гістарычна - археалагічны зборнік. Т. 11. Беларусь у сістэме Еурапейскіх културных сувязяу. Мінск, 1997, с. 15-20.

11 Lietuvių etnogenezè. Vilnius, 1987, p. 126. 
žygiais ${ }^{12}$. E. Jovaiša mano, kad tai ne hunų, o akacirų žygių pėdsakai ${ }^{13}$. Tribriaunių (kitaip - trisparnių) strèlių antgalių randama ir Dniepro baltų genčių teritorijoje ${ }^{14}$. Neatmesčiau galimybès, jog šiuos antgalius galèjo palikti ne hunai ar akacirai, o VI a. Padunojèje (dab. Vengrijos teritorijoje ir aplinkinèse žemėse) ịsikūrę avarai. Veikiausiai baltų žemès patyrè ir hunų, ir avarų antpuolių. Atsekti šiuos procesus padettų kruopšti randamų tribriaunių strèlių antgalių ir hunų bei avarų kituose regionuose paliktų pédsakų lyginamoji analizè.

Baltai patyre ne tik hunų ir avarų, bet ir germaniškujjų gepidų, gotų, galbūt ir langobardų genčiu ịtaką. V. Šimènas, kruopščiai analizuodamas itin sudètingus etnokultūrinius procesus, vykusius vakarinèje baltų arealo dalyje I tūkstm. viduryje, ǐžvelgia nomadiškojo (klajoklių) paveldo apraiškų baltų kultūroje, pradedant su klajokliais sietinomis ịkapèmis kai kuriuose kapinynuose ir baigiant rašytinių šaltinių duomenimis apie kumyso (kumelių pieno) vartojimą prūsų žemėse ${ }^{15}$.

Baltų areale viduriniame geležies amžiuje vyko itin sudètingi etnokultūriniai procesai. Dèl tautų kraustymosi ị vakarinius ir rytinius baltų masyvo pakraščius pradejjo veržtis slavai. Rytiniame baltų gyvenamų žemių pakraštyje šis VI a. prasidęjęs procesas baigèsi VIII a. ${ }^{16}$ Baltų bendruomenès buvo asimiliuotos, o kai kurios veikiausiai sunaikintos karo veiksmų metu. Ilgiausiai (iki XI-XII a.) Okos aukštupio baseine, slavų apsuptyje, išliko V-VII a. gyvenusių Moščino kultūros baltų (siejamų su rytu galindais) paskutinès salos ${ }^{17}$.

12 Лухтан А. Война V века в Литве // Гістарычна - археалагічны зборнік. Т. 11. Беларусь у сістэме Еурапейскіх културных сувязяу. Мінск, 1997, с. 15-20.

13 Jovaiša E. Baltų visuomenè ankstyvųjų viduramžių pradžioje (V-VI a.) // Istorija. T. 64. Vilnius, 2006. Prieiga internete: http://www.istorijoszurnalas.lt/index.php?option=com content\&view=article\&id=18\&Itemid=2

14 Vitkūnas M. Baltų karyba viduriniame ir vèlyvajame geležies amžiuje. Dniepro baltai// Karo archyvas. T. XXIV. Vilnius, 2009, p. 24, 7 pav., p. 31, 11 pav., p. 33.

15 Šimėnas V. Etnokultūriniai procesai Vakarų Lietuvoje pirmojo mūsų eros tūkstantmečio viduryje. Vilnius, 2006.

16 Vaškevičiūtė I. Baltai slavų apsuptyje // Istorija. T. 65. Vilnius, 2007. Prieiga internete: http://www.istorijoszurnalas.lt/index.php?option=com_content\&view=article\&id=45\&It emid=24

17 Vitkūnas M. Baltų karyba viduriniame ir vèlyvajame geležies amžiuje. Dniepro baltai // Karo archyvas. T. XXIV. Vilnius, 2009, p. 4-34. 
Centrinèje ir vakarineje baltų arealo dalyje šiuo laikotarpiu aiškiai išsiskyrè baltų gentys (prūsai, jotvingiai, lamatiečiai, skalviai, kuršiai, žemaičiai, žiemgaliai, aukštaičiai, lietuviai, sèliai, latgaliai), jos išliko iki pat viduramžių. Šių genčių tarpusavio sąveika taip pat buvo gana sudètinga, veikiama tam tikrų kultūrinès įtakos, migracijos, asimiliacijos procesų. Prūsai iš savo žemių branduolio - Sembos pusiasalio - pasislinko ị pietus ir îsikūrè plačioje teritorijoje prie Vyslos žemupio ${ }^{18}$.

Apskritai vidurinis geležies amžius baltų žemèse pasižymèjo nuoseklia žemdirbystès (be lydiminès, buvo plètojama ir dvilaukè) ir gyvulininkystès plètra (apie 90 proc. kaulų, randamų šio laikotarpio archeologijos paminkluose, sudaro naminių gyvulių kaulai). Metalurgijoje, auksakalystèje ryškejja specializacija, dideja meistrų profesionalumas. Plečiasi gyvenviečių tinklas (sparti jo plètra prasidèjo dar senajame geležies amžiuje), apleidžiami daugelis bendruomenių piliakalnių-ịtvirtintų gyvenviečių. Pagrindine gyvenvietės forma tampa atvira kaimavietè.

Tobulejo statyba, stulpinès konstrukcijos pastatus keitè rentiniai statiniai $^{19}$. Sunkiau rekonstruojami socialiniai vidurinio geležies amžiaus procesai, tačiau akivaizdu, kad tuo metu išsiskyrè genties diduomenè ir kariaunos.

\section{SVARBIAUSI V-VIII A. BALTŲ KARYBOS TYRIMAI}

Geriausiai ištirtas vidurinio geležies amžiaus baltų karybos aspektas, be abejo, yra ginkluotè. Ginklas - dažniausiai aptinkamas karybos artefaktas, o laidojimo paminklai, kuriuose randama ịkapemis tapusių ginklų, išsamiausiai ištirta vieno ar kito laikotarpio archeologijos paminklų $\operatorname{grupè~}^{20}$. Tai galima pasakyti ir apie vidurini geležies amžių. Dauguma šio laikotarpio ginklų (išskyrus strèlių antgalius) taip pat rasta laidojimo paminkluose.

Iki šiol išsamiausią senojo ir vidurinio geležies amžių ginkluotės ty-

\footnotetext{
18 Lietuvos istorija. T. 2. Geležies amžius. Vilnius, 2007, p. 190-191.

19 Ten pat, p. 293-297.

20 Ši taisyklè negalioja tik Lietuvos priešistorei iki Kristaus. Kur kas daugiau tirta akmens ir ankstyvojo metalų laikotarpių gyvenviečių, nei laidojimo paminklų. O laikotarpiu nuo senojo geležies amžiaus iki viduramžių datuojamų paminklų grupejje kur kas geriau nei gyvenvietès ir piliakalniai ištirti laidojimo paminklai.
} 
rimų studiją yra paskelbęs V. Kazakevičius ${ }^{21}$. Ją svariai papildè specialios publikacijos, skirtos vienašmeniams kalavijams ${ }^{22}$, strèlių antgaliams ${ }^{23}$ aptarti. Savo ilgamečių tyrimų duomenis V. Kazakevičius apibendrino habilitaciniame darbe „Geležies amžiaus baltų genčių ginkluotè“24. Jo darbai išlieka labai aktualūs ne tik Lietuvos, viso baltų regiono, bet ir Europos karybos istorijos tyrimų kontekste.

Ne mažiau svarbūs ir atskiriems ginkluotès tipams skirti darbai. V. Šimènas daug dėmesio skyrè smailiųjų kovos peilių-durklų problematikai25. Kovos ir darbo kirvius, jų tipologiją ir ergonomiką aptarè A. Malonaitis ${ }^{26}$.

Daugelyje publikacijų, kuriose skelbiama laidojimo paminklų medžiaga, skiriama dèmesio rastiems ginklams. Fortifikacijos duomenu galima rasti darbuose apie vidurinio geležies amžiaus piliakalnius ir ju i̇rengimą. Šiuo klausimu daugiausia yra rašę V. Daugudis ${ }^{27}$ ir G. Zabiela ${ }^{28}$.

Nepranoktas darbas apie daugelį vidurinio geležies amžiaus laikotarpio reiškinių ir procesų dabartinès Lietuvos teritorijoje - šiam laikotarpiui skirta A. Tautavičiaus monografija ${ }^{29}$. Baltų visuomenès sanklodos, struktūros bruožus vidurinio geležies amžiaus pradžioje išanalizavo ir reikšmingų pastebejjimų apie to meto karybą, kariaunas, baltų kovas su

21 Казакявичюс В. Оружие балтских племен II-VIII веков на территории Литвы. Вильнюс, 1988.

22 Kazakevičius V. Vienašmenių kalavijų atsiradimas ir raida Lietuvoje // Lietuvos archeologija. T. 2. Vilnius, 1981, p. 43-58.

23 Kazakevičius V. Geležies amžiaus strèlès Lietuvoje II-XII/XIII a. Vilnius, 2004.

24 Kazakevičius V. Geležies amžiaus baltų genčių ginkluotè. Habilitacinis darbas. Vilnius, 1998.

25 Šimėnas V. Smailieji kovos peiliai-durklai baltų kraštuose I m. e. tūkstantmečio viduryje // Vidurio Lietuvos archeologija. Etnokultūriniai ryšiai. Vilnius, 1996, p. 27-71; Šimènas V. Etnokultūriniai procesai Vakarų Lietuvoje pirmojo mūsų eros tūkstantmečio viduryje. Vilnius, 2006, p. 74-93; Шименас В. Боевые ножи - кинжалы в Балтийском ареале в V-VI вв. // Археология и история Пскова и Псковской земли. Псков, 1992, c. $96-100$.

26 Malonaitis A. Geležiniai siauraašmeniai kirviai Lietuvoje. Vilnius, 2008.

27 Daugudis V. Aukštadvario piliakalnio pastatai ir įtvirtinimai // MADA, T. 1(12), Vilnius, 1962, p. 43-69; Daugudis V. Seniausieji mediniai pastatai ir įrengimai Lietuvoje // MADA, T. 2(75), Vilnius, 1981, p. 61-73; Daugudis V. Senoji medinè statyba Lietuvoje. Vilnius, 1986.

28 Zabiela G. Lietuvos medinès pilys. Vilnius, 1995.

29 Tautavičius A. Vidurinis geležies amžius Lietuvoje (V-IX a.). Vilnius, 1996. 
svetimomis bendruomenèmis pateikè E. Jovaiša ${ }^{30}$.

Kariaunų atsiradimo problemas iš lietuvių autorių plačiausiai tyrinejjo L. Vaitkunskienè $\dot{e}^{31}$, taip pat V. Kulakovas ${ }^{32}$.

Specializuotų baltų karių kovos taktikos viduriniame geležies amžiuje studijų iki šiol nebuvo. Šiuos klausimus fragmentiškai aptarẻ V. Kazakevičius $^{33}$ ir Baltarusijos karo istorikas E. Novikovas ${ }^{34}$.

Archeologiškai labai sunkiai atsekami kariniai veiksmai. Vis dèlto analitiškai žvelgiant ị gausią tyrimų medžiagą įmanoma atkurti labai įdomius praeities ịvykius. Turime omenyje A. Luchtano straipsnị, kuriame, remdamasis vien archeologiniais duomenimis, autorius gana argumentuotai pagrindžia nuomonę, jog V a. j̇ Lietuvos teritoriją ịsiveržè tam tikros stepių klajoklių (veikiausiai hunų) pajègos, nurodo jų pultas vietoves ir apytikslį žygio maršrutą ${ }^{35}$. Teiginius apie hunų ar kitų klajoklių issiveržimo ị baltų žemes galimybę dar anksčiau kèlè V. Kazakevičius ir V. Šimėnas, tačiau A. Luchtanas šią temą išplètojo.

30 Jovaiša E. Baltų visuomenè ankstyvųjų viduramžių pradžioje (V-VI a.) // Istorija. T. 64. Vilnius, 2006. Prieiga internete: http://www.istorijoszurnalas.lt/index.php?option=com_ content\&view=article\&id=18\&Itemid=2

31 Vaitkunskienė L. Pagrybio kapinynas. Lietuvos archeologija. T. 13. Vilnius, 1995, p. 163-166; Vaitkunskienè L. The formation of warrior elite during the Middle Iron Age in Lithuania // Archaeologia Baltica. T. 1. Vilnius, 1995, p. 94-106; Вайткунскене Л. К вопросу о начале дружины в Литве // Задачи советской археологии в свете решений XXVII сьезда КПСС: Тезисы докладов (Суздаль, 1987 г.). Москва, 1987, с. 56-57.

32 Кулаков В. Начало дружины пруссов // Всесоюзная конференция по изучению истории, археологии, экономики, литературы и языка скандинавских стран и Финляндии. Тезисы докладов. Москва, 1986, с. 188-190; Кулаков В. Дружинные элементы в могильниках пруссов VII - начале XI в. // Археологческие памятники Европейской части РСФСР: Погребальные памятники. Москва, 1988, с. 119-145; Кулаков В. Знамена дружин балтского региона // Советская археология. Москва, 1989, № 4, с. 61-70; Кулаков В. Погребения военачальников прусских дружин // Краткие сообщения Института археологии Академии наук СССР. Москва-Ленинград, 1989, вып. 198, с. 35-44.

33 Kazakevičius V. Geležies amžiaus baltų genčių ginkluotė. Habilitacinis darbas. Vilnius, 1998, p. 60-61.

34 Новікаў Я. Ваенная гісторыя Беларускіх земляў (да канца ХІІ ст.). Том 1. Мінск, 2007.

35 Лухтан А. Война V века в Литве // Гістарычна - археалагічны зборнік. Т. 11. Беларусь у сістэме Еурапейскіх културных сувязяу. Мінск, 1997, с. 15-20. 


\section{GINKLUOTE்}

Ginklai tradiciškai skirstomi į keletą grupių: artimosios (kontaktinės) kovos - kalavijai, kirviai, smogiamosios ietys, peiliai, buožès, tolimosios (distancinès) kovos - lankai su strèlemis, svaidomosios ietys, akmenu svaidyklès - ir apsauginiai - skydai, šalmai, šarviniai marškiniai, šarvai. Labai dažnai toks skirstymas (ypač skiriant artimosios ir tolimosios kovos ginkluotę) yra santykinis. Igudusio kario rankose dažniausiai artimajai kovai skirtas kirvis ar peilis gali būti taikliai nusviedžiamas ir ị tolèliau esantị priešą, o svaidomoji ietis, ịprastinis tolimosios kovos ginklas, - sèkmingai naudojama ir artimojoje kovoje. Tačiau principinis ginkluotès skirstymas $\mathfrak{i}$ artimosios ir tolimosios kovos ginklus išlieka aktualus norint suvokti, kokią dali ginkluotès jie sudarè, ir kelti tolesnes prielaidas aptariant galimai taikytą kovos taktiką.

Dar vienas svarbus ginkluotés tyrimų aspektas - kai kurių radinių (visų pirma kirvių ir peilių) priskyrimo prie ginklų arba darbo įrankių grupès problema. Manyčiau, jog ilgą laiką naudotas šių dirbinių skirstymas ị minètas grupes vien pagal išorinius estetinius požymius arba matmenis nẻra tikslus. Ypač tai pasakytina apie ydingą kirvių priskyrimą prie darbo i̇rankių arba ginklų vadovaujantis vien tuo, jog „ornamentuotas kirvis - ginklas, neornamentuotas - darbo ịrankis“. Šią tendenciją pastebime ir V. Kazakevičiaus darbe, kuriame jis tvirtina, kad, nagrinèdamas Lietuvos archeologinę medžiagą (1988 m. publikacija), suskaičiavęs per tūkstantị ịmovinių ir ịtveriamųjų kirvių ${ }^{36}$. Tačiau vadovaujantis logika, kad „kovos kirvis tik tas, kuris ornamentuotas arba kurio pentis su atkraštemis", ginklais gali būti laikomi tik $22^{37}$ ar vos $13^{38}$. Tyrejjas teigia, kad „kovos kirviai - viena iš ginklų rūšių, kuri aptinkama labai retai tarp kitų baltų materialinès kultūros daiktų. Šių smogiamųjų ginklų randama I tūkstm. vidurio ir antrosios pusés lietuviu pilkapiuose. Kovos kirvio formos paprastumas veikiausiai ir lèmé jo retumą. Tik ornamentas, masė ir kai kurios kitos labai nežymios, antraeilès detalès padeda atskirti kovos kirvị nuo darbinio, kuris, beje, taip pat sèkmingai galèjo pakeisti kovinị.

${ }^{36}$ Казакявичюс В. Оружие балтских племен II-VIII веков на территории Литвы. Вильнюс, 1988, с. 75.

37 Ten pat, p. 131.

38 Ten pat, p. 132. 
Pagal šias nereikšmingas detales ir išaiškejja kovos kirvio formos raida“". ${ }^{39}$ Vèliau, aptardamas visame baltų areale rastus kirvius, prie kovos kirvių V. Kazakevičius vėlgi priskyrẻ tik išsiskiriančius estetinėmis savybėmis (grakštesnių formų, ornamentuotus ir tuos, kurių kotai buvo apvynioti žalvarinèmis ornamentuotomis juostomis). Taip pat tyrejjas $\mathfrak{i}$ kovos kirvių grupę įtraukẻ kirvius su atsparinėmis (atkraštėmis) ${ }^{40}$. Baltų ginkluotès viduriniame geležies amžiuje kiekybinį santykị apibūdinančioje diagramoje kirviams tenka itin menka dalis - vos 1,7 proc. $^{41}$

Taigi, nors V. Kazakevičius kategoriškai ir neatmetè galimybès, kad ir „darbo“ kirviai galejo būti naudojami kaip kovos priemonè, tačiau jų ì ginkluotès sąrašą neịtraukè. Manyčiau, toks požiūris klaidingas. Kirvis - universalus dirbinys, tinkamas naudoti kaip darbo įrankis ir ginklas, todèl visus aptariamojo laikotarpio kirvius reikia vertinti ginkluotès kontekste ir jokiu būdu „nešalinti“ iš ginkluotès kompleksų vien dèl to, kad dauguma jų buvo neornamentuoti.

Ornamentuotų ir neornamentuotų kirvių, priklausančių I tūkstm. Lietuvos ir kitų baltiškų žemių archeologinei medžiagai, skirtumai visų pirma yra išoriniai, estetiniai, kas iš esmès nekeičia jų konstrukcinių savybių ir nemažina neornamentuoto kirvio panaudojimo kaip ginklo galimybių. Ornamentikoje vertètų ieškoti ne funkcinès paskirties skirtumų, o kirvių kaip jų turètojų turtingumo, tam tikro socialinio statuso, galbūt ir teiktos maginès galios ženklų. Tačiau ir čia galima nusukti ị klystkelius. Jei ornamentuotą kirvi griežtai laikysime turtingo kario, vado atributu, kyla klausimas, kodèl Taurapilio pilkapyno pilkapio Nr. 5 „kunigaikščio“ kape, kurio ịkapès labai turtingos, ịdètas neornamentuotas, gana kuklus siauraašmenis pentinis kirvis, o aiškiai žemesnio socialinio rango vyro kape pilkapyje Nr. 6 aptiktas kur kas prašmatnesnis ornamentuotas kirvis su atkraštemis ${ }^{42}$.

A. Malonaitis, apibendrinęs ir išanalizavęs Lietuvos teritorijoje ras-

39 Ten pat, p. 133.

40 Kazakevičius V. Geležies amžiaus baltų genčių ginkluotè. Habilitacinis darbas. Vilnius, 1998, p. 31-33.

41 Ten pat, p. 25, 3 diagrama.

42 Tautavičius A. Taurapilio „kunigaikščio“ kapas // Lietuvos archeologija. T. 2. Vilnius, 1981 , p. 28-36. 


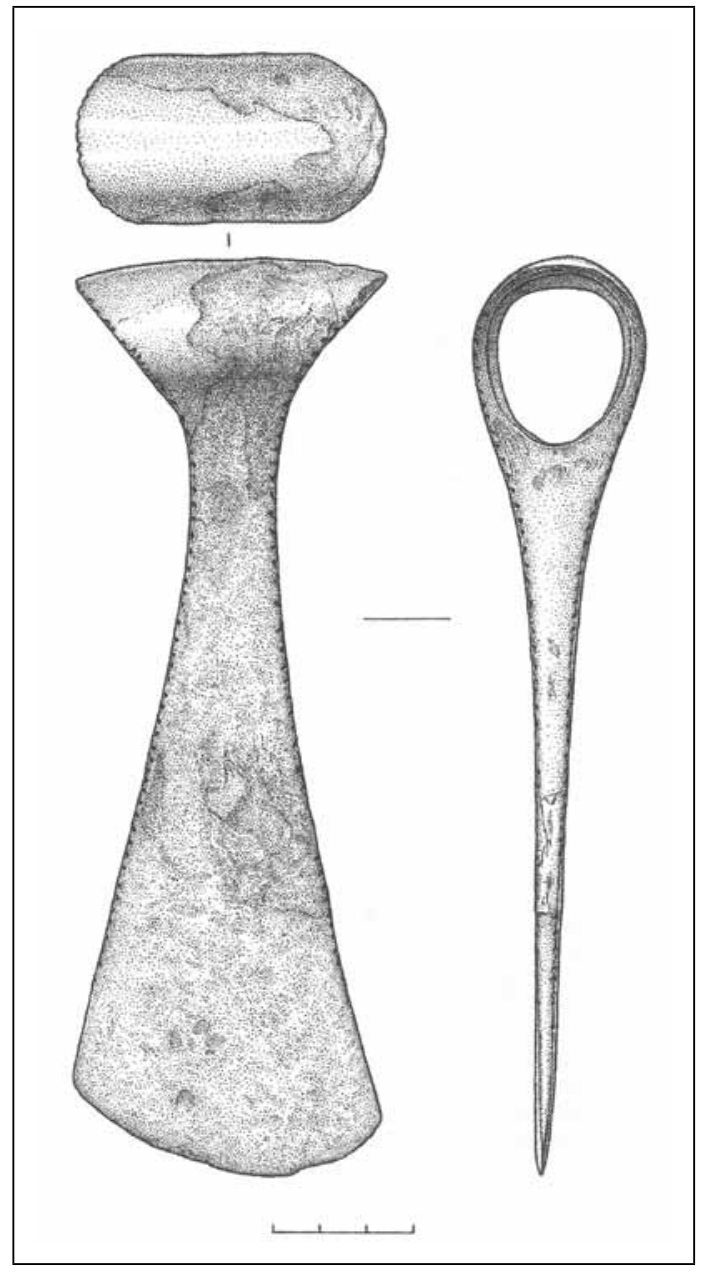

1 pav. Ornamentuotas kirvis

iš Neravų (Grigiškių) pilkapyno tų siauraašmenių kirvių duomenis, aiškiai įrodo, kad ornamentuoti kirviai nesudaro kažkokios vienos išskirtinès grupès. Anot A Malonaičio, „ornamentuotieji kirviai nèra vienodi, todèl nereikia jų visų suplakti ir nagrinèti tik kovos kirvių aspektu“. Pavyzdžiui, aptardamas 7-ojo tipo kirvius (beje, jų chronologija visiškai atitinka vidurini geležies amžių), išsiskiriančius nedidele mase, siauru pleištu, plačiais ašmenimis, dažnai ovalia koto kiauryme (šis apibūdinimas leidžia laikyti tokio tipo kirvius itin tinkamais kovai), A. Malonaitis pažymi, kad tarp jų pasitaike ir ornamentuotų, ir neornamentuotuc egzempliorių. Tas pat pasakytina ir apie kitu tipų kirvius ${ }^{43}$.

Labai įdomios ir A. Malonaičio išvados, padarytos atlikus siauraašmenių kirvių ergonominius tyrimus. Aptardamas minèto 7-ojo tipo kirvius, jis teigia, jog tiek ornamentuoti, tiek neornamentuoti šio tipo

43 Malonaitis A. Geležiniai siauraašmeniai kirviai Lietuvoje. Vilnius, 2008, p. 89. 
kirviai turèjo būti ilgakočiai (kotai - 50-90 cm ilgio). Kitų tipų ornamentuotų kirvių kotų ilgis atitinka dažniausiai pasitaikančius ${ }^{44}$. Vadinasi, ir ornamentuotų, ir neornamentuotų to paties tipo kirvių kotai turëjo būti panašūs. Tai labai svarbi išvada, jei manysime, kad kovos kirvis turèjo būti maunamas ant gana ilgo koto. Tačiau ar kovos kirvis būtinai turi būti ilgakotis? A. Malonaitis linkęs manyti, kad, nors ilgas kotas ir leidžia padidinti smūgio jègą, kovai toks kirvis vargu ar tiktų, nes būtų gremėzdiškas. Jị esą visą laiką tektų laikyti rankose, o ne pritvirtintą prie diržo. A. Malonaitis spejja, jog kirvis turèjo būti ne ilgesnis už kalaviją, ir teigia, kad šiandien pasitaikančios ilgakotès kirvių rekonstrukcijos yra nepagrịstos. Esą manevravimo tokiu įrankiu galimybes atskleidžia atlikti ergonominiai tyrimai. „Žinoma, galima ịsivaizduoti ịvairiai ir sakyti, kad ilgakočiu kirviu galima pasiekti toliau esantị priešininką ar pan., bet taip gamtos neapgausime. ${ }^{" 45} \mathrm{Su}$ paskutiniu teiginiu nesinorètų sutikti. Ankstyvųjų viduramžių Europoje buvo gerai žinomi dvirankiai ilgakočiai kovos kirviai, kuriuos naudojo pėstininkai. Tokiu kirviu ginkluotas karys kautynių metu skydą, kuris kabojo ant diržo, permesdavo už nugaros ir kaudavosi laikydamas ilgą kirvio kotą abiem rankomis ${ }^{46}$. Be abejo, toks ginklas turejjo savų trūkumų ir privalumų. Juo buvo galima pasiekti toliau esantị karị, jo smogiamoji jèga buvo didelè, tačiau netaiklus smūgis praktiškai nepalikdavo galimybių ištaisyti klaidos ir išvengti atsakomojo priešo smūgio. Tačiau, susidūrus su raitu priešininku, ilgakotis kirvis tapdavo ne tik puikiu kertamuoju ginklu, bet ir priemone, leidžiančia užkabinti ir nuversti raiteli žemèn. Visos šios išvardytos priežastys neleidžia kategoriškai atmesti galimybès, kad baltų kariai bent dali kirvių maudavo ant ilgų (galbūt $1,5 \mathrm{~m}$ ) kotų, nors neabejotinai vyravo kirviai gerokai trumpesniais $(0,5-1,0 \mathrm{~m})$ kotais.

Dar vienas klausimas, $\mathfrak{i}$ kurị iki šiol nebandyta ieškoti atsakymo - ar baltai kirvius kovoje naudojo tik kaip kertamuosius artimosios kovos, ar ir kaip svaidomuosius ginklus tolimiems taikiniams kauti? Kirvius svaidyti ankstyvaisiais viduramžiais buvo puikiai igudę įvairių Europos regionų kariai. Frankai labai plačiai naudojo kelių tipų svaidomuosius vie-

\footnotetext{
44 Ten pat.

45 Ten pat.

46 Догерти М. Д. Средние века. Искусство войны. Москва, 2009, с. 100.
} 
našmenius ir dviašmenius kovos kirvius - vadinamąsias „fransiskas “ ${ }^{47}$. Tarp Lietuvos archeologinių radinių kirvių, savo forma atitinkančiu "fransiskas", neturime, tačiau neatmestina galimybė, kad igudę baltų kariai ir vietinių tipų kirvius kartais galëjo naudoti kaip svaidomuosius ginklus. Šią prielaidą galima patvirtinti arba atmesti tik eksperimentinès archeologijos metodu.

Akivaizdu, kad kirviams, vertinant jų vietą baltų karių ginkluotèje, kol kas skirta pernelyg mažai demesio. Jei atmestume V. Kazakevičiaus suformuluotą nuostatą, kad kovos kirvis būtinai turi būti ornamentuotas, ir ịtrauktume visus kirvius ị bendrą ginklų skaičių, jo išskirtos I tūkstm. Lietuvoje naudotos ir archeologų aptiktos ginkluotès (apie 1260 ietigalių, apie 280 kalavijų, apie 100 kovos peilių, vos 22 kirviai) ${ }^{48}$ proporcijos esmingai pasikeistų. Daugiau kaip 1000 iki 1988 m. visų tipų Lietuvoje rastų ir V. Kazakevičiaus suskaičiuotu (tikslesnę ir naujesnę kirvių duomenų bazę pateikia A. Malonaitis) ${ }^{49}$ kirvių ịtraukus i ginkluotès kompleksus, paaiškètų, kad kirvių rasta nedaug mažiau nei iečių. Ietis ir kirvis turètų būti pagrindinis ir dažniausiai pasitaikantis ginklų kompleksas. Be abejo, tolesni tyrimai turètų remtis detalia kapuose aptiktų ikapių kompleksų analize.

Dèl ieties, kaip dažniausiai naudoto ir, natūralu, dažniausiai aptinkamo baltų karių ginklo reikšmingumo abejonių nekyla. Pagrindinè problema - atskirų tipų ietigalių priskyrimas prie smogiamųjų arba svaidomųjų iečių. Šis skirstymas taip pat gana sąlygiškas, nes kiekvieną ietị (išskyrus itin sunkias falangos karių ietis) galima naudoti abiem atvejais - viskas priklauso nuo konkrečios kovinès situacijos ir kario fizinio pajègumo. Visgi tam tikras tendencijas įžvelgti galima. Smogiamosioms ietims būdingas masyvus ietigalis. Tačiau išskirti kurị nors vieną jų tipą, tik kaip svaidomųjų arba smogiamụjų iečių ietigalių, gana sunku, nes tipologiškai net tam pačiam tipui priskiriami ietigaliai būna labai ịvairaus dydžio, nors jų formos ir yra beveik identiškos (pvz., antrojo tipo pagal V. Kazakevičiaus tipologiją įmovinių ietigalių randama nuo beveik $11 \mathrm{~cm}$

47 Разин Е. А. История военного искусства VI-XVI вв. Москва, 1999, с. 127.

48 Казакявичюс В. Оружие балтских племен II-VIII веков на территории Литвы. Вильнюс, 1988, с. 130-131.

49 Malonaitis A. Geležiniai siauraašmeniai kirviai Lietuvoje. Vilnius, 2008. 
iki daugiau nei $45 \mathrm{~cm}$ ilgio) $)^{50}$. Iš esmès vieninteliai tik svaidomosioms ietims pritaikyti veikiausiai buvo ịtveriamieji ietigaliai, tačiau jų Lietuvos teritorijoje randama nedaug, daugiausia - sèlių žemèse. Kur kas daugiau šio tipo ietigalių aptikta dabartinès Latvijos teritorijoje, Skandinavijoje, frankų žemèse. Suomijoje „angono“ tipo ietigaliai apskritai laikomi kone „nacionaliniu“ ugrų-suomių ginklu, nors Estijoje tokių ietigalių randama visai nedaug. Lietuvoje rasti vos keli „angono“ tipo ietigaliai ${ }^{51}$.

Germanų žemèse vienas pagrindinių ginklų ilgą laiką buvo „framèja“ - nedidelè, vos ilgesnè nei pusantro metro ietis. Jos lapo formos ietigalis buvo platus, todèl tokia ietis galejo būti naudojama ne tik toli svaidyti, bet ir artimajame mūšyje. Ja buvo atliekami duriamieji, o suèmus kotą abiem rankomis - ir kertamieji smūgiai ${ }^{52}$. Galbūt panašią dvigubą funkciją galèjo turèti ir kai kurių tipų baltų ietys.

Taigi ir ietigalių priskyrimo prie svaidomųjų arba smogiamųjų iečių kriterijų paieškos klausimas lieka atviras ir tampa dar vienu ginkluotès tyrimų, kuriems atlikti reikalingi eksperimentai, aspektu. Tačiau jau dabar drịstu kelti hipotezę, kad daugeliu atvejų ietis buvo naudojama kaip svaidomasis ginklas. Ieties vieta ginkluotès komplekse priklausė nuo to meto kovos taktikos, kario materialinès gerovès ir galimybių apsiginkluoti. Bet kokiu atveju dažniausiai kario ginkluotės kompleksą sudarè ietis ir kirvis. Šie ginklai itin dažnai randami baltiškojo regiono karių kapuose, datuojamuose nuo geležies amžiaus iki pat viduramžių. Abu juos naudoti mūšyje vienu metu būtų sunku, nebent kirvis yra užkištas ar kitaip pritvirtintas prie kario diržo ar juostos, kol jis kaunasi ietimi. Manyčiau, ginklų naudojimo mūšyje schema galejjo būti tokia: mūšio pradžioje, priartejus tinkamu atstumu, buvo sviedžiama svaidomoji ietis, o tada puolamas priešas (tiesioginis kontaktas) kaunantis kirviu (kalaviju arba smogiamąja ietimi). Peilis naudotas savigynai dèl kokių nors priežasčių praradus pagrindinị ginklą (kirvị, kalaviją arba smogiamąją ietị išmušus iš rankų, jiems lūžus ir pan.) arba pribaigiant priešą.

50 Казакявичюс В. Оружие балтских племен II-VIII веков на территории Литвы. Вильнюс, 1988, с. 36.

51 Ten pat, p. 57-63.

52 Тараторин В. История боевого фехтования. Развитие тактики ближнего боя от древности до начала XIX века. Минск, 1998, с. 144. 


\section{BALTŲ KARYBA}

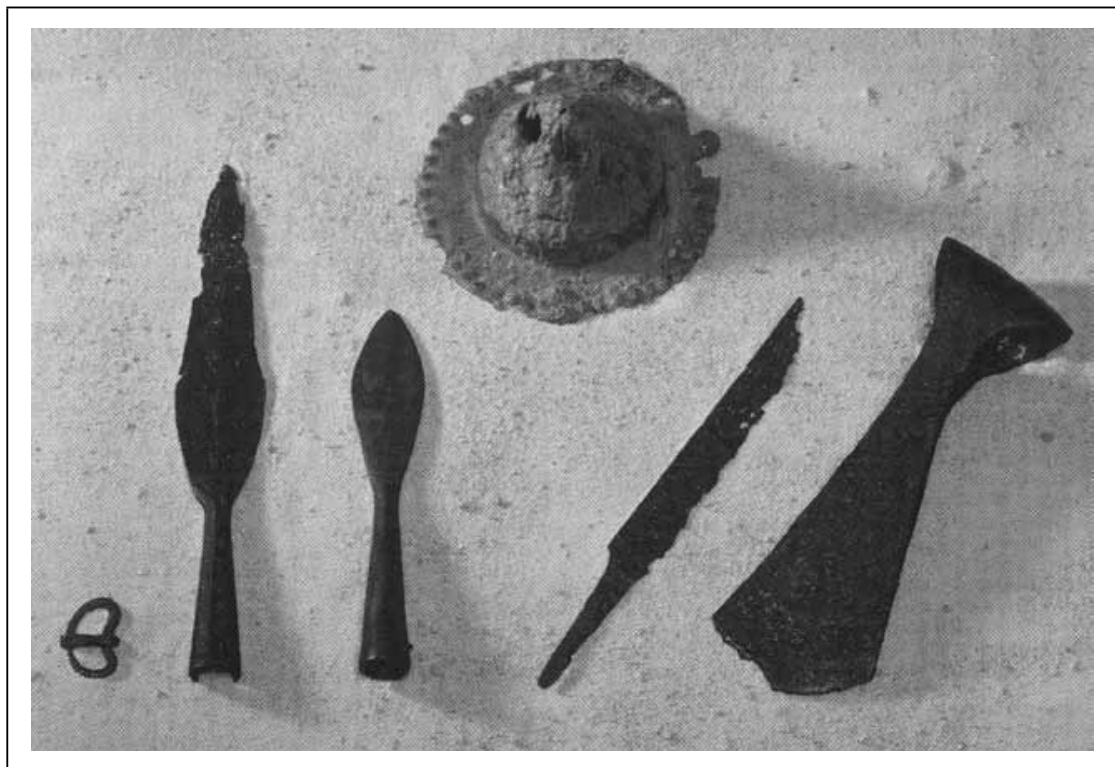

2 pav. Popų-Vingelių pilkapyne (Elektrėnų sav.), pilkapyje Nr. 2, kape Nr. 1, rastos kario ikapès: sagtis, du ietigaliai, kirvis ir skydo umbas

Kartais kariai kapuose palaidoti su dviem ir daugiau iečių. Tokiu atveju taktinis šių ginklų naudojimo paaiškinimas yra toks: mūšio pradžioje karys sviedžia vieną ar kelias lengvesnes svaidomąsias ietis ir lieka rankoje laikydamas sunkesnę smogiamąją ietį arba ima kitą ginklą. V. Kazakevičius yra pateikęs keliomis ietimis ginkluotų karių veiksmų schemą: „Kariai veikiausiai turèjo kelis iečių kompleksus - smogimui ir svaidymui iš artimo nuotolio. Pradėdami mūš̌i, jie naudojo svaidomąsias ietis, o vèliau jau iš artimo atstumo stodavo ị susirèmimą. Ietys su ietigaliu maža, siaura plunksna labiau tiko svaidymui. Jomis buvo pristabdomas priešo puolimas. O ietys, turejjusios ietigalị su didele, plačia plunksna, tiko artimai kovai. Jos padarydavo didelius, smarkiai kraujuojančius sužalojimus, nuo kurių priešo kariai greitai silpdavo ir išeidavo iš rikiuotès. " ${ }_{33}$

Svarbus L. Vaitkunskienès pastebejjimas atlikus Žemaitijos Pagrybio kapinyno (Šilalès r.) tyrimus: visuose kapuose, kuriuose rasti du ietiga-

53 Казакявичюс В. Оружие балтских племен II-VIII веков на территории Литвы. Вильнюс, 1988, с. 17-18. 
liai, vienas iš jų buvo su didele, plačia, kitas - gerokai smulkesne, siauresne plunksna ${ }^{54}$.

Kariui, ginkluotam viena ietimi arba ietimi ir peiliu, paleisti ietị iš rankų būtų buvę labai rizikinga. Jis ją turètų naudoti ne tik kaip tolimosios, bet ir kaip artimosios kovos ginklą. Būtų tikslinga atlikti analizę, ar kariai, palaidoti su viena ietimi ir be kirvio arba kalavijo, nebuvo ginkluoti sunkesne, labiau duriamiesiems smūgiams pritaikyta ietimi.

Kartais kapuose randama ne viena ar dvi, o trys, keturios ar net penkios ietys. V. Kazakevičius mano, kad tiek daug iečių kariui turèti nebuvo reikalo, nes tai būtų kèlę problemų. Esą „toks iečių skaičius reiškia, kad turtinè nelygybè viduriniajame geležies amžiuje buvo toli pažengusi ir jau atsiradusios prielaidos giliam socialiniam bendruomenių

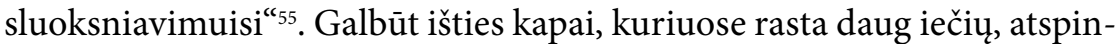
di ryškèjančią socialinę stratifikaciją, tačiau nebūčiau tikras, kad karys su keturiomis ar penkiomis ietimis negalejo eiti ị mūši. Dar antikos laikais buvo daugybė atvejų, kai lengvieji pėstininkai nešdavosi ị mūšį kelias ietis, kurias vèliau vieną po kitos išsvaidydavo ị priešą ir traukdavosi ị savo pajėgų užnugarị arba tęsdavo kovą artimosios kovos ginklais (kalavijais ir pan.). Pavyzdžiui, antikos laikais itin vertinti trakų lengvieji pèstininkai imdavo ị mūš̨̀ kelias svaidomąsias ietis ${ }^{56}$.

Peilis arba kovos peilis-durklas - dar vienas ginklas, kurị buvo galima naudoti tiek artimojoje kovoje, tiek ị priešą svaidyti. Ginkluotę tiriantys archeologai jau prieš daugeli dešimtmečių susidūrè su problema: ką vadinti peiliu, o ką - kovos peiliu ar kalaviju. Čia svarbūs R. VolkaitèsKulikauskienės ir V. Kazakevičiaus tyrimai, kuriuos aptarè ir toliau šią specifinę sritį nagrinèjo V. Šimènas. Anot jo, dabar egzistuojantis ginklų skirstymas pagal dirbinių geležtès ilgị (peiliai iki $25 \mathrm{~cm}$ ilgio vadinami buitiniais, nuo 25 iki $50 \mathrm{~cm}$ - koviniais, nuo $50 \mathrm{~cm}$ - kalavijais) yra tobulintinas, bet iš esmès priimtinas ${ }^{57}$.

54 Vaitkunskienė L. Pagrybio kapinynas. Lietuvos archeologija. T. 13. Vilnius, 1995, p. 106-107.

55 Kazakevičius V. Geležies amžiaus baltų genčių ginkluotė. Habilitacinis darbas. Vilnius, 1998, p. 28.

56 Энглим С., Джестис Ф., Райс Р., Раш С., Серрати Д. Войны и сражения Древнего мира. 3000 год до н. э. - 500 год н. э. Москва, 2007, с. 28-30.

57 Šimėnas V. Etnokultūriniai procesai Vakarų Lietuvoje pirmojo mūsų eros tūkstantmečio viduryje. Vilnius, 2006, p. 74. 


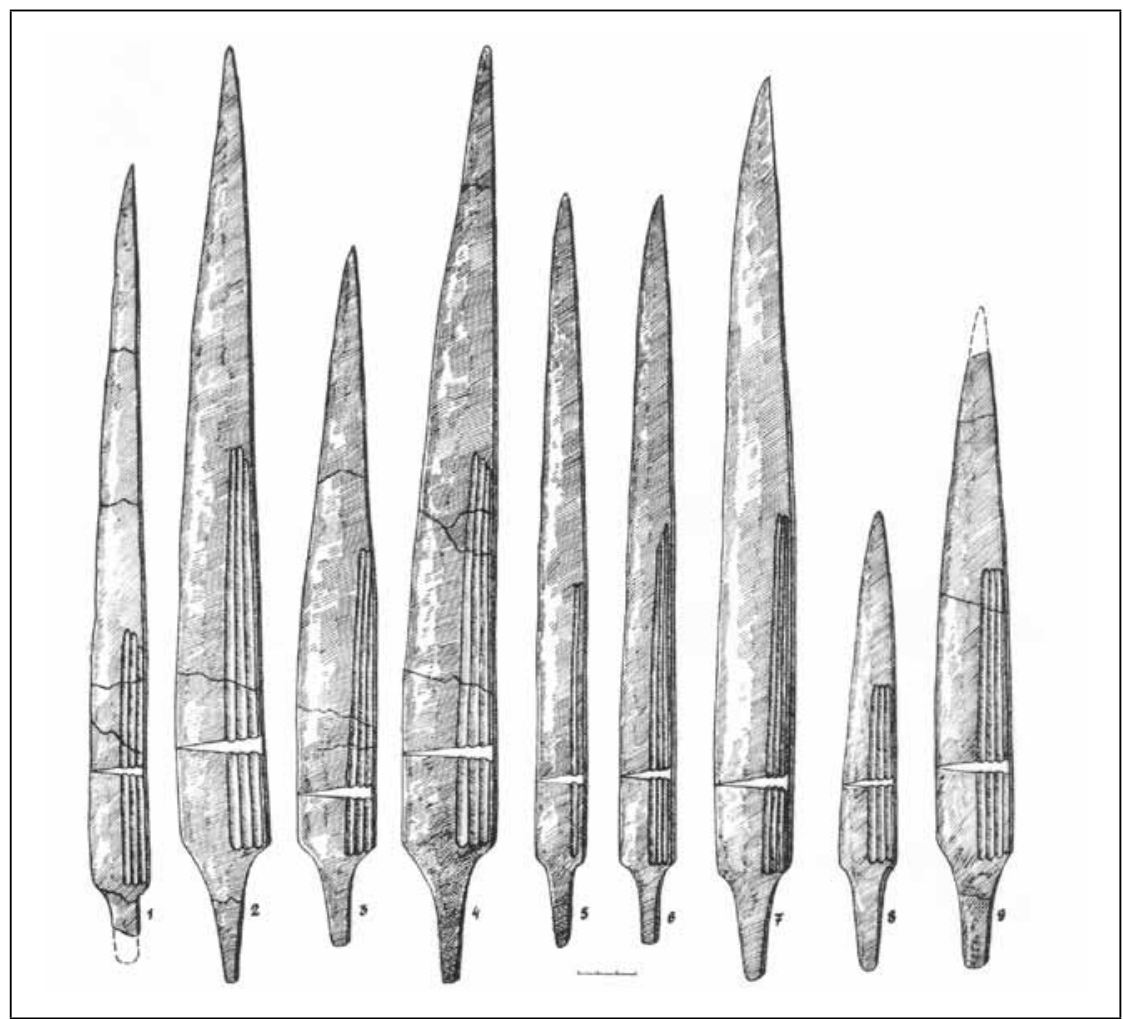

3 pav. Kovos peiliai-durklai iš Vidgirių kapinyno (Pagègių sav.)

V. Šimėnas savo tyrimuose daug dėmesio skyrè savitam šios grupès ginklui - smailiajam kovos peiliui-durklui išskirti ir aptarti. Šiems $25-56 \mathrm{~cm}$ ilgio ginklams būdinga siaura, ištęsta, siauru smaigaliu geležtė ir trumpa ¡kkote. Jų geležtės dažniausiai puoštos horizontaliais grioveliais (kurie senesnèje literatūroje kartais vadinami „grioveliais kraujui nutekèti“). Smailiųjų kovos peilių-durklų svorio centras dažniausiai yra arti geležtės. Jie dèl trumpos ịkotès netiko kertamiesiems smūgiams (galèjo lengvai išlūžti iš medinès arba kaulinès rankenos) atlikti, tačiau puikiai buvo pritaikyti durti. Tokių ginklų gausiau randama prūsų žemèse, mažiau - Nemuno žemupyje (skalvių žemèse) ir Vidurio Lietuvoje (aukštaičių žemėse). Pavienių egzempliorių aptikta kuršių, žemaičių žiemgalių genčių gyventose teritorijose. Jie, anot V. Šiméno, atsirado V a. viduryje ir buvo segami prie 


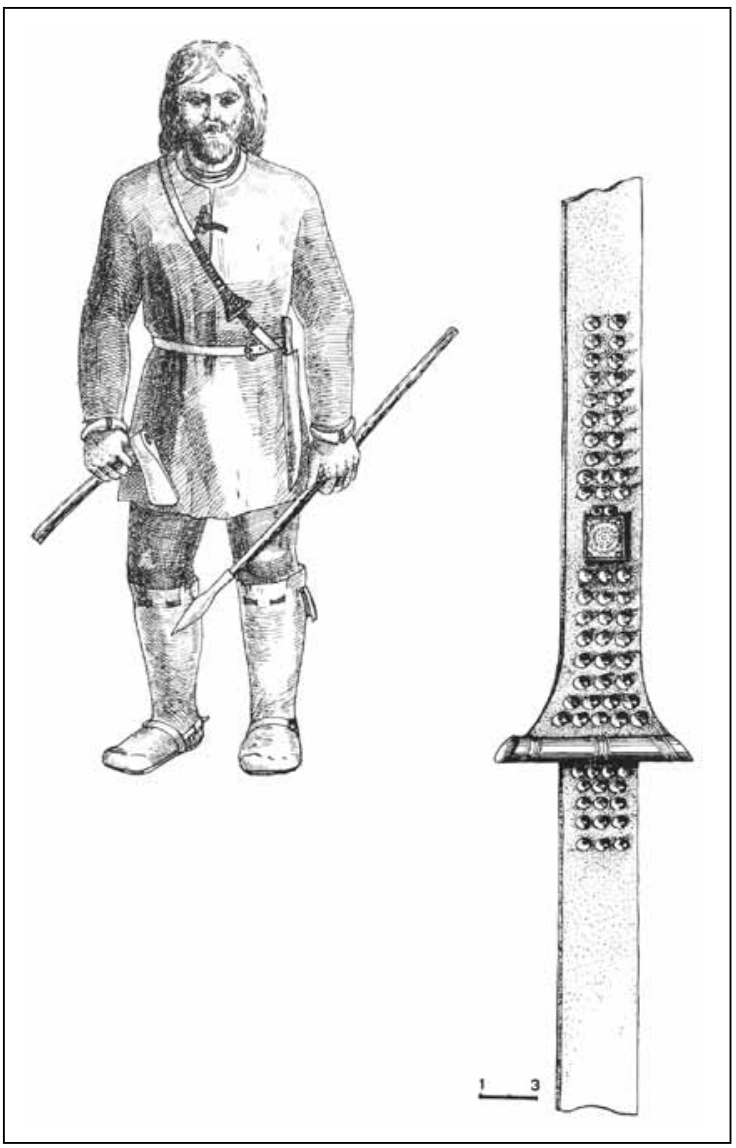

4 pav. Perpetè ir jos nešiojimo būdo rekonstrukcija, remiantis Vidgirių kapinyno (Pagėgių sav.) tyrimų duomenimis

diržų ir perpečių, prie pastarųų buvo tvirtinami ir kalavijai. Perpečių nešiosenos tradicijos ištakų ieškant romėnų ir barbarų kontaktų zonoje Dunojaus vidurupyje ${ }^{58}$ nustatyta, jog jos baltų kraštuose pradejo plisti $\mathrm{V}$ a.

Pastebima, kad smailiujuc kovos peilių-durklų ir apskritai durti skirtų smailejančių kovos peilių naudojimo pradžia susijusi su akivaizdžiai didesniu vidurinio geležies amžiaus pradžios gerai ginkluotų karių kapų skaičiumi. Marvelès kapinyne (dab. Kauno ribos) dažniausiai randamą (70 proc. vyrų, palaidotų su ginklais, kapų) ginkluotès kompleksą sudaro ietis, kirvis ir peilis. Kiti kompleksai (durklas + ietis arba durklas +2 ietys, arba tik durklas) gerokai retesni. Ši tendencija patvirtina mano prielaidą dẻl trijų tipų ginklų (ieties, kirvio, peilio) naudojimo trijuose skirtinguose individualių kautynių etapuose (svaidomosios ieties smūgis artejjant prie priešo, kirvio tiesioginiai smūgiai artimojoje

58 Ten pat, p. 74-93. 
kovoje vyras prieš vyrą ir prireikus peilio arba durklo panaudojimas savigynai arba priešui pribaigti).

Be smailiųjų kovos peilių-durklų, kapuose aptinkama ir kitų tipų peilių. Beveik visada vienintelis jų priskyrimo prie ginklų kriterijus - geležtès ilgis (anot V. Kazakevičiaus, Lietuvoje nusistovejusi tradicija koviniais laikyti peilius ne trumpesne kaip $20 \mathrm{~cm}$ geležte, o bendras tokių peilių ilgis siekia nuo $25 \mathrm{iki} 50 \mathrm{~cm}$ ). Remdamasis šiais kriterijais praejjusio amžiaus devintojo dešimtmečio pabaigoje V. Kazakevičius buvo suskaičiavęs apie 100 kovos peilių, tačiau smulkiau tipizuoti jų nesièmè $\dot{~}^{59} .1998 \mathrm{~m}$. habilitaciniame darbe jis jau drąsiau kèlè prielaidą, jog kai kurie „ị buitinius panašūs peiliai“ galèjo būti naudojami ir karybai, bet neatsisakè nuostatos, kad jie būtinai turèjo būti ilgi $(25-50 \mathrm{~cm})^{60}$.

Ar tikrai galima peilius vien tik pagal geležtès ilgị kategoriškai skirstyti ị kovos ir buitinius? Esu tikras, kad ne. Smailiųjų kovos peilių-durklų kitos funkcijos, išskyrus kovinę (dūrimo), yra labai ribotos dèl V. Šimèno išryškintų minètų konstrukcinių ypatumų. Tačiau kitų tipų peiliai iš esmès tiko tiek kautynių, tiek buitiniams veiksmams (maistui pjaustyti, ivvairiems smulkiems darbams žygio sąlygomis ir pan.) atlikti. Peilis su gerai kote įtvirtinta $10-15 \mathrm{~cm}$ ilgio geležte buvo gana veiksmingas duriamasis ar kertamasis savigynos ginklas, juo labiau jis tiko priešui pribaigti, vaizdžiai tariant, perpjauti jam gerklę ar durti ị širdị. Esu tikras, kad nepriskirti prie ginkluotès peilių trumpesne nei $20 \mathrm{~cm}$ geležte taip pat klaidinga, kaip ir nelaikyti ginklais neornamentuotų kirvių. Toks laikymasis anksčiau nustatytų sutartinių matmenų ar požymių šiais laikais dirbtinai „nuginkluoja“ daug praeities karių ir apskritai iškreipia kario ginkluotės komplekso sampratą. Būčiau linkęs laikytis visiškai priešingos nuomonès - bet kuris peilis atitinkamoje situacijoje gali būti naudojamas tiek kaip darbo įrankis, tiek kaip ginklas. Netgi moterų rankose peilis veikiausiai buvo ne tik buitinis įrankis, bet ir savigynai nuo, tarkime, užpuoliko, plèšiko ar prievartautojo tinkamas ginklas.

59 Казакявичюс В. Оружие балтских племен II-VIII веков на территории Литвы. Вильнюс, 1988, с. 82-92.

60 Kazakevičius V. Geležies amžiaus baltų genčių ginkluotè. Habilitacinis darbas. Vilnius, 1998, p. 34-35. 


\section{Kalavijai}

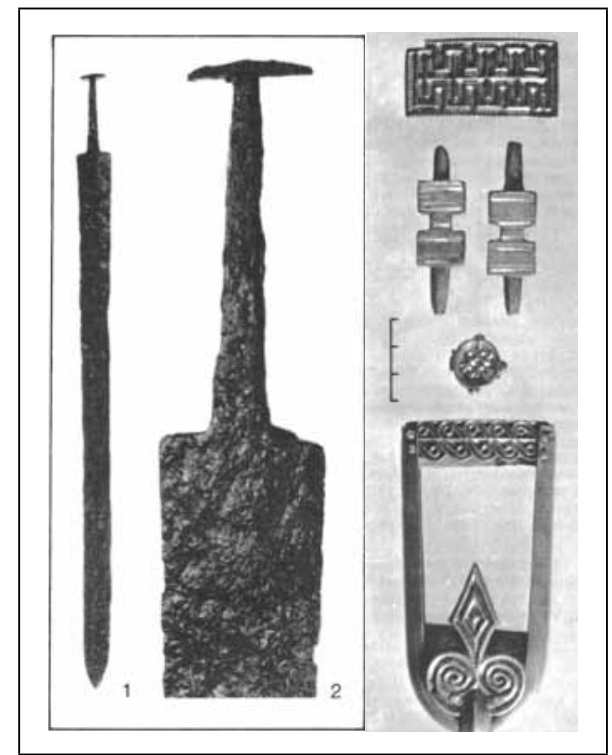

5-6 pav. Dviašmenis kalavijas ir sidabrinès

paauksuotos kalavijo makščių apkalos iš

Taurapilio pilkapyno (Utenos r.) pilkapio Nr. 5

Anot V. Kazakevičiaus, baltų žemėse vidurinio geležies amžiaus paminkluose rasta apie 480 kalavijų. Tik du iš jų yra dviašmeniai (rasti Taurapilyje ir Krikštonyse, laikomi „importiniais“, atgabentais iš Padunojès), apie 130 vienašmenių kalavijų (daugiausia rastų vakarineje baltu arealo dalyje) ir apie 350 plačiųjų kalavijų ${ }^{61}$. Itin ịdomus baltams būdingas ginkluotès tipas - platieji kalavijai (dar vadinami plačiaisiais kovos peiliais-kalavijais). Jų dažniausiai aptinkama žiemgalių, rečiau - latgalių ir žemaičių, labai retai - sèlių laidojimo paminkluose. Žemaičiai apie IX a. plačiuosius kovos peilius-kalavijus nustojo naudoti, o žiemgaliai juos naudojo iki pat viduramžių pradžios. Anot tyrejjų, to meto plačiųjų kovos peilių-kalavijų paplitimo žemėlapis iš esmès atitinka žiemgalių teritorijos kontūrus ${ }^{62}$. Tokių peilių-kalavijų platusis galas paprastai yra $4-9 \mathrm{~cm}$ pločio, bendras ginklo ilgis - 27-53 cm. Kartais kapuose randama ir miniatiūrinių, vos 13-24 cm ilgio, plačiųjų kovos peilių-kalavijų. Manoma, kad tai - tikrųjų ginklų simbolinès ịkapès ${ }^{63}$.

Kalavijai (ypač labai reti - dviašmeniai) sietini su gentine diduomene ir kariaunomis. Kiek komplikuotas yra tik plačiųjų kalavijų, kurie, ga-

61 Ten pat, p. 29-31.

62 Vaškevičiūtė I. Žemgaliai V-XII amžiuje. Vilnius, 2004, p. 55.

63 Казакявичюс В. Оружие балтских племен II-VIII веков на територии Литвы. Вильнюс, 1988, с. 114. 


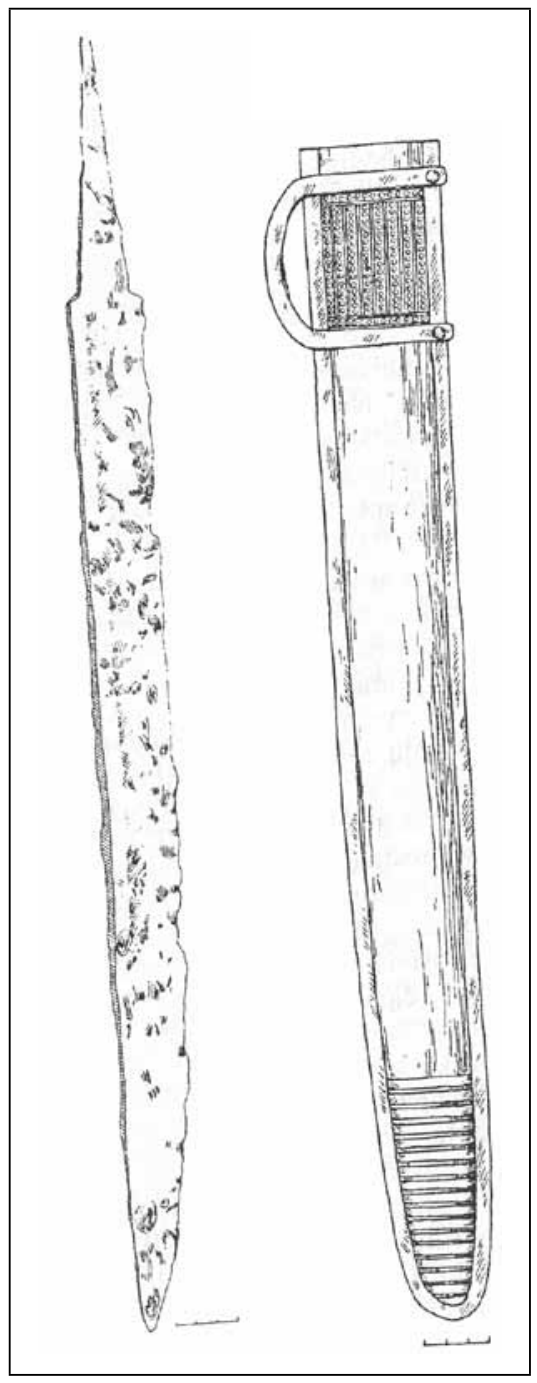

7-8 pav. Vienašmenis kalavijas, rastas

Pagrybio kapinyno (Šilalès r.) kape

Nr. 10, ir pagal kapų Nr. 10 ir Nr. 158 radinius rekonstruotos kalavijo makštys lima sakyti, buvo masiškai paplitę žiemgalių žemèse, priskyrimas šioms socialinèms grupèms. Panašu, jog platusis kalavijas buvo tiek žiemgalių kariauninkų - profesionalių karių, tiek pašauktinių - eilinių bendruomenès narių - dažnai naudojamas ginklas.

Lankai ir strèlés neabejotinai taip pat buvo naudojami baltu karyboje, tačiau jų reikšmè kol kas labiausiai neaiški dèl dviejų priežasčių: vidurinio geležies amžiaus kapuose strèlių antgalių nerandama (išskyrus kelis, aptiktus žmonių palaikuose kaip sužalojimų pédsakai, o ne ikkapès), dalis piliakalniuose rastų strèlių antgaliụ yra aiškiai svetimų etninių grupių karių puolimų pédsakai (pvz., klajoklių hunų ir avarų naudotų strèlių trisparniai antgaliai). Akivaiz$\mathrm{du}$, kad lankas ir strèlès tam tikru mastu buvo naudojami karyboje, tačiau nebuvo tradicijos dèti strèliụ ị kapus.

Senojo, vidurinio ir vèlyvojo geležies amžiaus strèlių antgalius išsamioje tam specialiai skirtoje studijoje yra apžvelgęs ir jų katalogą paskelbęs V. Kazakevičius ${ }^{64}$. Jame aiškiai matyti, kad didesnè dalis viduriniam geležies amžiui prisikirtinų antgalių yra klajoklių

${ }^{64}$ Kazakevičius V. Geležies amžiaus strèlès Lietuvoje II-XII/XIII a. Vilnius, 2004. 


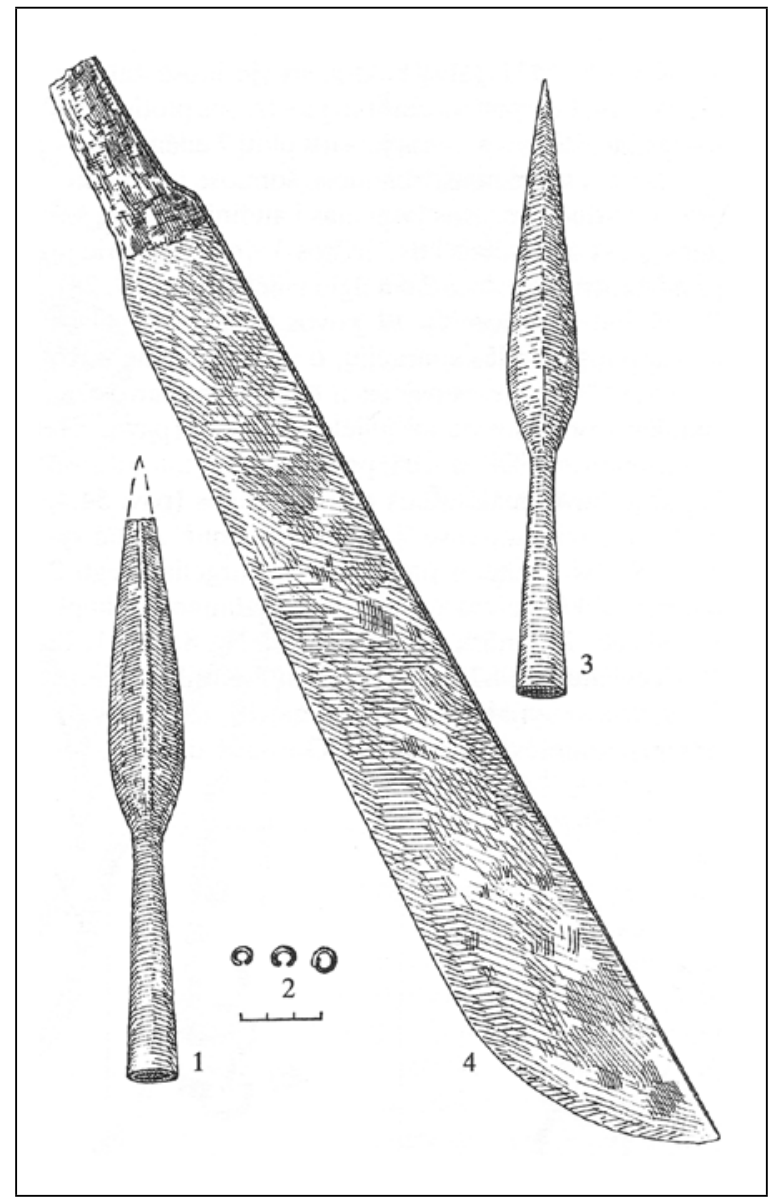

9 pav. Platusis kovos peilis - kalavijas, grandelès ir ietigaliai, rasti Šukionių kapinyno (Pakruojo r.) kape Nr. 13

strèlių trisparniai antgaliai. Aptariamam laikotarpiui taip pat priskiriama dalis imoviniu strèlių antgalių su užbarzdomis (jų chronologija apima visą I t-meti ir II t-mečio pradžią, o kilmé sietina ir su baltais, ir su slavais bei germanais; rastas 31 antgalis) ${ }^{65}$. Tokios pat plačios chronologijos, būdingos dideliam Rytu Europos arealui, yra ir itveriamieji strèlių atgaliai rombo (rasti 66 vnt.) bei lapo formos plunksnelèmis $(9 \text { vnt. })^{66}$. V. Kazakevičius pastebi, kad strèlių antgalių dabartinès Lietuvos teritorijoje nuo senojo iki vèlyvojo geležies amžiaus palaipsniui gausèja, tačiau jie bendroje ginklų statistikoje sudaro tik $1,7-7,9$ proc. Ši reiškini bandyta aiškinti to meto Lietuvos gamtinès (geografinès) aplinkos ypatumais, dideliu miškingumu.

\footnotetext{
65 Ten pat, p. 19-23.

66 Ten pat, p. $41-53$.
} 
Esą miškingoje teritorijoje lankas ir strèlès apskritai naudoti rečiau, dažniau - per pilių apgulas. Be to, po mūšio surinktos strèlès buvo pakartotinai naudojamos ${ }^{67}$. Tenka sutikti su šiomis mintimis. Turèdami lanką ir strèles kaip ginkluotès dalị, nepatekusią $\mathfrak{i}$ laidojimo papročius ir netapusią jkapèmis, esame priversti tenkintis strèlių antgaliais, rastais atliekant piliakalnių, rečiau - atvirų gyvenviečių tyrimus. Šiuose objektuose bet kokių kitų tipų ginklai yra reti radiniai. Be to, vidurinio geležies amžiaus piliakalnių ir gyvenviečių apskritai tirta gana nedaug. Gali būti, kad dèl to strèlių antgalių aptariamojo laikotarpio archeologinèje medžiagoje yra nedaug. Tačiau manyti, kad baltai išvis labai retai naudojo lanką ir strèles, vargu ar būtų teisinga. Visų pirma, dar nuo ankstyvojo metalų laikotarpio lankai ir strèlès mūsų žemėse naudoti plačiai. Vien Narkūnų piliakalnyje rasta apie 40 kaulinių strèlių antgalių ${ }^{68}$. Mažai tikètina, kad dar iki Kr. baltų žemèse sukaupta lankų ir strèlių gamybos, šaudymo iš lanko patirtis staiga būtų buvusi prarasta ir dèl to atsisakyta didžiausiu šūvio nuotoliu galimo naudoti tolimosios kovos ginklo. Manyčiau, būtent dèl anksčiau minètu objektyvių priežasčių tiek mažai strèlių antgalių esama bendroje baltiškoje archeologineje medžiagoje. Lankai ir strèlès veikiausiai buvo naudojami kur kas dažniau, nei mes galime spręsti iš randamų artefaktų, juo labiau kad tuo metu ir kaimyniniuose kraštuose šie ginklai buvo paplitę. Lankais ginkluotus VI a. slavų karius mini to laikotarpio Bizantijos autoriai ${ }^{69}$. Germanų kraštuose lankai taip pat nebuvo išnykę. IV a. datuojamoje aukojimo vietoje Nydamo vietoveje Danijoje rasta 40 lankų ir daugiau nei 170 strè$\operatorname{lių}^{70}$. Tačiau apskritai germanų žemèse lankai pagal populiarumą, manoma, nusileido tik svaidomosioms ietims ${ }^{71}$. Panaši tendencija pastebima ir baltų žemèse.

Ten pat, p. $75-78$.

${ }^{68}$ Grigalavičienė E. Žalvario ir ankstyvasis geležies amžius Lietuvoje. Vilnius, 1995, p. 113.

69 Разин Е. А. История военного искусства VI-XVI вв. Москва, 1999, с. 38.

70 Randsborg K. Scandinavian armies. Military organization before the Viking Age // Archaeologia Baltica. T. 2. Vilnius, 1997, p. 112-113.

71 Тараторин В. История боевого фехтования. Развитие тактики ближнего боя от древности до начала XIX века. Минск, 1998, с. 141. 


\section{Apsauginè ginkluotè}

Apsauginę ginkluotę baltų žemėse viduriniame geležies amžiuje pirmiausia reprezentuoja skydai. V. Kazakevičius baltų areale jų suskaičiavo apie 90, t. y. šiek tiek mažiau nei senojo geležies amžiaus archeologijos paminkluose (kuriuose rasta apie 100). Tačiau skydai buvo gana plačiai paplitę visame baltų areale (jų fragmentų nerasta tik latgalių ir Dniepro

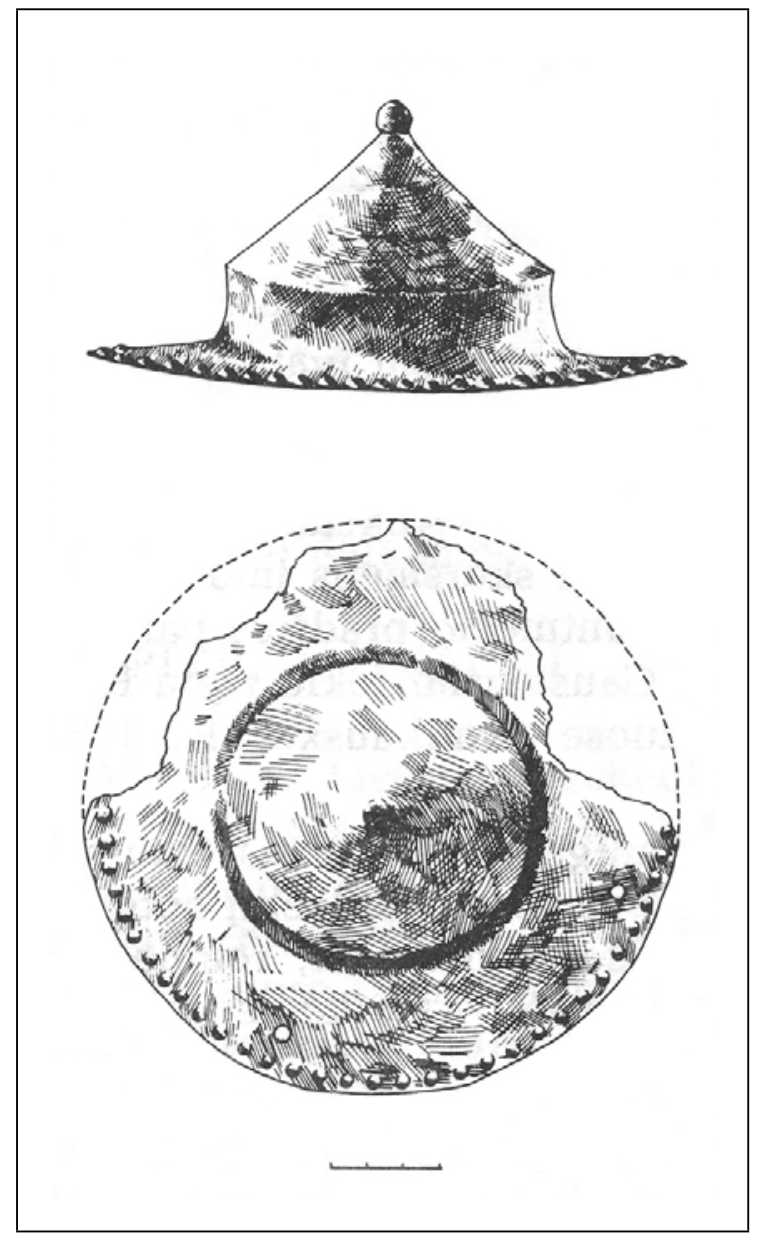

10 pav. Antskydis (skydo umbas) iš Krikštonių (Lazdijų r.) baltų žemèse). Ir toliau vyrauja kūgio formos geležiniai skydo umbai, žinomi dar nuo senojo geležies amžiaus. Rečiau randama pusrutulio formos umbų, metalinių skydų rankenų dalių ir skydų kraštu apkalų. V. Kazakevičius atkreipia demesi it tai, kad VII-VIII a. kapuose baltų žemėse skydų metalinių detaliu jau neberandama. Jis spejja, kad plačiau paplito vien iš medžio daryti skydai, kurių likučių aptikti iš esmès neịmanoma, taip pat kelia prielaidą, jog skydas su umbu ir kitomis metalinèmis detalemis vidurinio geležies 
amžiaus pabaigoje prarado monopolinę gynybinio ginklo poziciją, mat netrukus jau vėlyvojo geležies amžiaus ginkluotėje atsirado šarvinių marškinių, metalinių šalmų ir jie pamažu plito ${ }^{72}$.

Iš tiesų šarvuotès elementų rasta jau vidurinio geležies amžiaus paminkluose Dniepro baltų žemèse ${ }^{73}$. Bene ankstyviausių baltų žemėse šarvų fragmentų, datuojamų VII-VIII a., rasta Koločino kultūros areale. Moščionkos (Ukraina, Černigovo sritis) piliakalnio Koločino kultūrai priskiriamame kultūriniame sluoksnyje rasta žiedinių šarvų fragmentų ${ }^{74}$. Tame pačiame piliakalnyje aptikta ir plokštelinių šarvų fragmentų ${ }^{75}$. Labai tikètina, kad ir kitose baltų arealo dalyse jau viduriniame geležies amžiuje galejo būti naudojami bent jau pavieniai šarvuotès elementai, tačiau archeologinių tyrimų metu jie nebuvo atpažinti (pvz., šarvinių marškinių elementai pavadinti „grandelèmis“, šarvų plokštelès - „apkalèlèmis“).

\section{Ginkluotès raidos tendencijos}

V. Kazakevičius pastebejjo keletą labai svarbių baltų ginkluotės raidos viduriniame geležies amžiuje aspektų: Didysis tautų kraustymasis suteikè naują postūmị ginkluotei tobulèti. Buvo peržiūrima senoji ginkluotè, karybos formos, aktyviai ieškoma naujų, tobulesnių, atsirado naujų rūšių ginklų, juos išmokta naudoti ${ }^{76}$. V. Kazakevičius išskiria du viduriniame geležies amžiuje naudotos ginkluotès kompleksus - sunkųji (sudaro 2-3 ietys su skirtingų formų ietigaliais, vienašmenis arba platusis kalavijas, skydas, kovos kirvis, kovos peilis ir žirgas) ir lengvąji (2 ietys, skydas, kovos peilis ir retkarčiais lankas su strèlemis). Pirmasis kompleksas, anot

72 Kazakevičius V. Geležies amžiaus baltų genčių ginkluotè. Habilitacinis darbas. Vilnius, 1998, p. 17, 33-34.

73 Vitkūnas M. Baltų karyba viduriniame ir vèlyvajame geležies amžiuje. Dniepro baltai // Karo archyvas. T. XXIV. Vilnius, 2009, p. 22-23.

74 Щукин М. Семь сезонов Славяно-сарматской экспедиции // Итоги археологических экспедиций. Ленинград, 1989, с. 112.

75 Лупиненко Ю. Пластинчатый доспех восточных славян в VII-X вв. // Русь на перехресті світів (міжнародні впливи на формування давньоруської держави) IX-XI ст. Матеріали міжнародного польового археологічного семінару (ЧернігівШестовиця, 20-23 липня 2006 р.). Чернігів, 2006, с. 115.

76 Kazakevičius V. Geležies amžiaus baltų genčių ginkluotè. Habilitacinis darbas. Vilnius, 1998, p. 54. 
V. Kazakevičiaus, sietinas su kariauna, antrasis - su eiliniais bendruomenininkais ${ }^{77}$. Mano manymu, ankstesni teiginiai dèl kai kurių ginkluotès elementų (pirmiausia - dèl kirvių ir peilių) vertinimo sudaro prielaidas šiek tiek patikslinti V. Kazakevičiaus ginkluotès kompleksų schemą, tačiau principinis jų skirstymas ị sunkųji (raitelio) ir lengvąji (pėstininko) ginkluotès kompleksus yra pagrịstas.

Apžvelgus vidurinio geležies amžiaus baltų ginkluotès tendencijas paaiškèjo, jog šiuo klausimu dar galima daug diskutuoti. Reikia tęsti ginkluotès kompleksų analizę remiantis kapinynų tyrimų medžiaga. Taip pat būtini eksperimentiniai archeologiniai tyrimai, kurių metu būtų atliekamos ginklų rekonstrukcijos siekiant išsiaiškinti vienų ar kitų tipų ginklų realaus panaudojimo mūšyje galimybes.

\section{KARIAUNŲ ATSIRADIMO IR RAIDOS KLAUSIMAS}

Vienas sudėtingiausių baltų karybos istorijoje - kariaunų atsiradimo klausimas. Kariauna dažniausiai laikomas profesionalių, pirmiausia iš karo žygių gyvenančių, karių būrys, susitelkęs apie savo vadą. E. Gudavičius kariauną apibrèžia kaip „raitụjų karių būrị, susitelkusį aplink genties vadą, vèliau kunigaikštị “78. Germanų žemèse kariaunų atsirado I a. pr. Kr.-I a. po Kr., slavų žemèse - ne vèliau kaip IX a.

Lietuvių kariauna rašytiniuose šaltiniuose bene pirmą kartą paminèta Henriko Latvio kronikoje, aprašant lietuvių kunigaikščio Žvelgaičio žygi i estų žemes $1205 \mathrm{~m}$. („<...>lettonai, apie du tūkstančius ju raiteliu užpuolè estus. Ir kai lettonai slinko palei Dauguvą ir èjo pro Ryga, ị ši miesta su savo draugais j̇žengè vienas turtingas ir galingas letttonas, vardu Svelgate" "79. Be abejo, pagal pirmąji paminejjimą rašytiniuose šaltiniuose nenustatysime, kada iš tikrųjų susiformavo kariaunos. Neabejotina, kariaunų baltų žemèse atsirado kur kas anksčiau nei XIII a. pradžioje.

Ar jų jau buvo viduriniame geležies amžiuje? Šiuo klausimu arche-

77 Ten pat, p. 60-61.

78 Gudavičius E. Kariauna // Lietuvos istorija. Enciklopedinis žinynas. T. 1. Vilnius, 2011, p. 739; Gudavičius E. Kariauna // Visuotinè lietuvių enciklopedija. T. 9. Vilnius, 2006, p. 423.

79 Latvis H., Vartbergė H. Livonijos kronikos. Vilnius, 1991, p. 37-38. 
ologų nuomonès gerokai skiriasi. Bene daugiausia dèmesio kariaunų atsiradimo klausimams skyrusi Laima Vaitkunskiene dabartinëje Lietuvos teritorijoje atsiradusias kariaunas linkusi datuoti V-VI a. ${ }^{80}$ Anot jos, jau senajame geležies amžiuje žemdirbių bendruomenèse tam tikras vaidmuo buvo skiriamas kariams - raiteliams, o ginklų turèjo visi bendruomenès vyrai, nepriklausomai nuo amžiaus ir socialinès padèties. Nuo V-VI a. situacija keičiasi - randama nemažai šio laikotarpio vyrų kapų (Pagrybio kapinyne Šilalès r. - kiek daugiau nei pusè), kuriuose jie palaidoti be ginklų, o kituose - su ginklais. Ypač daug ginklų randama raitelių kapuose, kuriuose vyrai arba berniukai palaidoti su pentinais ir kamanų detalèmis ${ }^{81}$.

Anot E. Jovaišos, V a. antrosios pusės-VI a. pradžios laidojimo paminklai, ginklų tyrimai ir netiesioginiai rašytiniai šaltiniai leidžia teigti, kad kariaunų baltų žemése buvo jau $\mathrm{V}$ a. antrojoje puseje ${ }^{82}$.

Aptardamas kariaunų atsiradimo prūsų žemėse ypatumus V. Kulakovas atkreipia dèmesị $\mathfrak{i} \mathrm{V}$ a. pirmosios pusès prūsų laidojimo papročių permainas - rasta gerokai daugiau kapų, kuriuose palaidoti žirgai. Taip pat pastebima požymių, rodančių, kad kariaunose atsirado svetimšalių (pirmiausia germanų). Trečiuoju požymiu, liudijančiu, jog tuo metu formavosi kariaunos, anot V. Kulakovo, laikytinas polietinio ginklų dekoro stilius (pvz., Nogato žemupio kapinynuose rastų kalavijų makščių puošyboje susipina baltiški, germaniški ir avariški motyvai). Vis dèlto kariaunų formavimosi prūsų žemèse procesas, V. Kulakovo manymu, nebuvo labai staigus ir truko iki VII a. pabaigos ${ }^{83}$.

V. Žulkus išskiria du kariaunų („draugiju“) atsiradimo baltų žemèse etapus: V-VI a., kai, anot jo, , aptinkame pirmąsias draugijos apraiškas baltų visuomenèje", ir X a., kai prasideda antrasis kariaunų formavimosi etapas. Dauguma per pirmajj etapą sudygusių „draugijos daigų“, pasak

${ }_{80}$ Vaitkunskienè L. The formation of warrior elite during the Middle Iron Age in Lithuania // Archaeologia Baltica. T. 1. Vilnius, 1995, p. 94-106.

81 Vaitkunskienė L. Pagrybio kapinynas. Lietuvos archeologija. T. 13. Vilnius, 1995, p. 163-166.

82 Jovaiša E. Baltų visuomenè ankstyvųjų viduramžių pradžioje (V-VI a.) // Istorija. T. 64. Vilnius, 2006. Interneto prieiga: http://www.istorijoszurnalas.lt/index.php?option=com_ content\&view $=$ article\&id $=18 \&$ Itemid $=2$

83 Кулаков В. И. Пруссы (V-XIII вв.). Москва, 1994, с. 147-148. 
V. Žulkaus, veikiausiai sunyko, nes vargu ar visais atvejais grịžusių būrių vadai sugebejjo visuomenèje užimti ịtakingą padètị, kuri jiems būtų leidusi naujai organizuoti tradicinę vietos visuomenę $e^{84}$.

A. Tautavičius taip pat laikosi nuomonès, jog kariaunos baltų žemėse atsirado gana vèlai - X-XI a. Esą V-IX a. kapinynuose rasti su ginklais palaidoti vyrai greičiausiai yra ne kariaunos kariai, o laisvieji bendruomenès nariai - žemdirbiai. A. Tautavičius teigia, kad ginklai vyro kape liudija jo, kaip laisvojo bendruomenès nario - žemdirbio, padėtị, ir rodo, kad kiekvienas bendruomenès narys prireikus galejjo būti ir karys. Kariauna turètume vadinti didesnị ar mažesnị karių profesionalų būrị, dažnai ịvairios etninès sudèties, pavaldų kunigaikščiui ir jo išlaikomą ${ }^{85}$ Su šia hipoteze noréčiau sutikti tik iš dalies. Neabejotina, kad kariauna buvo profesionalių karių junginys, tačiau nebūtinai etniškai mišrus, atvirkščiai - tai pasitaikydavo gana retai ir veikiausiai dèl ịvairių atsitiktinių aplinkybių. Ginkluotès kompleksai, randami vidurinio geležies amžiaus karių kapuose, yra išties labai ịvairios sudèties ir turtingumo. Pavyzdžiui, niekaip žemdirbiais negalètume pavadinti A. Tautavičiaus tirtame Taurapilio pilkapyne (Utenos r.) palaidotų karių. Čia tirtas „kunigaikščio“ kapas (pilkapyje Nr. 5), kuriame rastos labai turtingos įkapès (žirgas, dviašmenis kalavijas makštyse su sidabriniais ir netgi paauksuotais puošybos elementais, dvi ietys, kirvis, skydas, pentinai, geriamasis ragas, papuošalų ir t. t.). Ganètinai turtingi buvo ir netoli šio kunigaikščio (neabejotinai kariaunos vado) palaidoti kiti kariai ${ }^{86}$. Gana panašus ikkapių kompleksas rastas ir visiškai kitame regione tirtame Pagrybio kapinyno (Šilalès r.) kapas Nr. 85, kuriame buvo palaidotas vyras su vienašmeniu kalaviju, dviem ietimis, geriamuoju ragu, peiliu, pentinu (jo dirželio apkalai buvo pasidabruoti), žirgo galva su žąslais, papuošalais (tarp jų - sidabrine antkakle). Tame pačiame kapinyne, kape Nr. 193, palaidotas vyras buvo išlydètas ị amžinybę su vienašmeniu kalaviju, ietimi, kirviu, peiliu, pentinu, arklio galva, kojomis, kamanomis ir žąslais. Kape Nr. 62 palaidoto vyro ne visos įkapès išliko, tačiau jame rastas vienašmenis kalavijas, ietigalis,

84 Žulkus V. Kuršiai Baltijos jūros erdvèje. Vilnius, 2004, p. 173-176.

85 Tautavičius A. Vidurinis geležies amžius Lietuvoje (V-IX a.). Vilnius, 1996, p. 284.

86 Tautavičius A. Taurapilio „kunigaikščio“ kapas // Lietuvos archeologija. T. 2. Vilnius, 1981, p. 28-36. 
sidabrinè antkaklè ir kitų papuošalų. Be to, greta šio vyro palaidota moteris, L. Vaitkunskienès nuomone, galèjo būti vergè, numarinta per kario laidotuves ir kartu su juo išlydèta $\mathfrak{i}$ anapusinị pasaulị ${ }^{87}$. Turtingų karių kapų rasta ir kitose baltiškojo arealo dalyse. I t-mečio vidurio kapus, priskirtinus kariniam elitui, išsamiai yra aprašęs E. Jovaiša ${ }^{88}$.

Taigi, vertinti akivaizdžiai karių kapus kaip žemdirbių būtų klaida. Manyčiau, jau vien keli minėti pavyzdžiai aiškiai rodo, jog vidurinio geležies amžiaus pradžioje baltų žemèse buvo susiformavęs karinio elito sluoksnis - kariauna. Jos narių kapai skiriasi nuo kapų, kuriuose taip pat rasta ginklų. Aptarti išsamiau kariaunos struktūrą būtų galima tik atlikus itin didelị darbą - peržiūrẻjus gausią kapinynų tyrimų medžiagą, išskyrus galimus kariaunos narių kapus pagal ginkluotę, kitas ịkapes. Galbūt tada pavyktų pastebèti ir specifinių laidojimo elementų. Taip pat būtina atkreipti demesị ị karių kapų vietą kapinyne. Taurapilio pilkapyne matome tarsi atskirą kariams laidoti skirtą pilkapyno dali. Pagrybio kapinyne tokio ryškaus kapų topografinio išskyrimo nepastebima.

Tik tolesni tyrimai padès atsakyti ir ị klausimą, kokia buvo kariaunų vidaus struktūra, pavaldumo sistema. Minètas E. Gudavičiaus pateiktas apibrèžimas, kad kariauna - tai „raitųjų karių būrys, susitelkęs aplink genties vadą, vèliau kunigaikštị “"89, taip pat nèra tikslus, nes ji nebūtinai turejo būti pavaldi genties vadui. Akivaizdu, jog viena gentis galejo turèti tikrai daugiau nei vieną kariauną, kaip ir ne vieną kunigaikštį. Svarbu suvokti, ką tiksliai turime galvoje vartodami sąvoką "gentis“. Archeologų ir istorikų darbuose šiuo terminu neretai vadinami gana skirtingo dydžio socialiniai, teritoriniai ir etniniai junginiai.

Galimas daiktas, kad kariaunos, bent jau atskirais laikotarpiais, buvo pavaldžios ne tik genties diduomenei ir savo vadams. V. Kulakovas kelia įdomią, tačiau silpnai pagrịstą prielaidą, esą prūsų žemèse kariaunos tam

${ }^{87}$ Vaitkunskienė L. Pagrybio kapinynas. Lietuvos archeologija. T. 13. Vilnius, 1995, p. 28-29, 51-52.

88 Jovaiša E. Baltų visuomenė ankstyvųjų viduramžių pradžioje (V-VI a.) // Istorija. T. 64 . Vilnius, 2006. Interneto prieiga: http://www.istorijoszurnalas.lt/index.php?option=com content\&view=article\&id=18\&Itemid=2

${ }^{89}$ Gudavičius E. Kariauna // Lietuvos istorija. Enciklopedinis žinynas. T. 1. Vilnius, 2011, p. 739; Gudavičius E. Kariauna // Visuotinẻ lietuvių enciklopedija. T. 9. Vilnius, 2006, p. 423. 
tikru laikotarpiu galèjo būti pavaldžios žyniams - kriviams ${ }^{90}$.

Esu tikras, kad kalbėti apie vidurinio geležies amžiaus pradžios kariaunas baltų žemèse galime be jokių išlygų. Minèti V-VI a. Pagrybio, Taurapilio ir kitų laidojimo paminklų kapai neabejotinai priklausė jau tuo metu aiškiai išsiskyrusiam kariniam elitui. Tačiau atsekti kariaunų raidos dinamiką vèlesniais amžiais, ypač vidurinio geležies amžiaus antrojoje pusejje, gali padèti tik nuodugni laidojimo paminklų medžiagos analizè. Gali būti, kad bent iš dalies pasitvirtins ir minèta V. Žulkaus iškelta dvie-

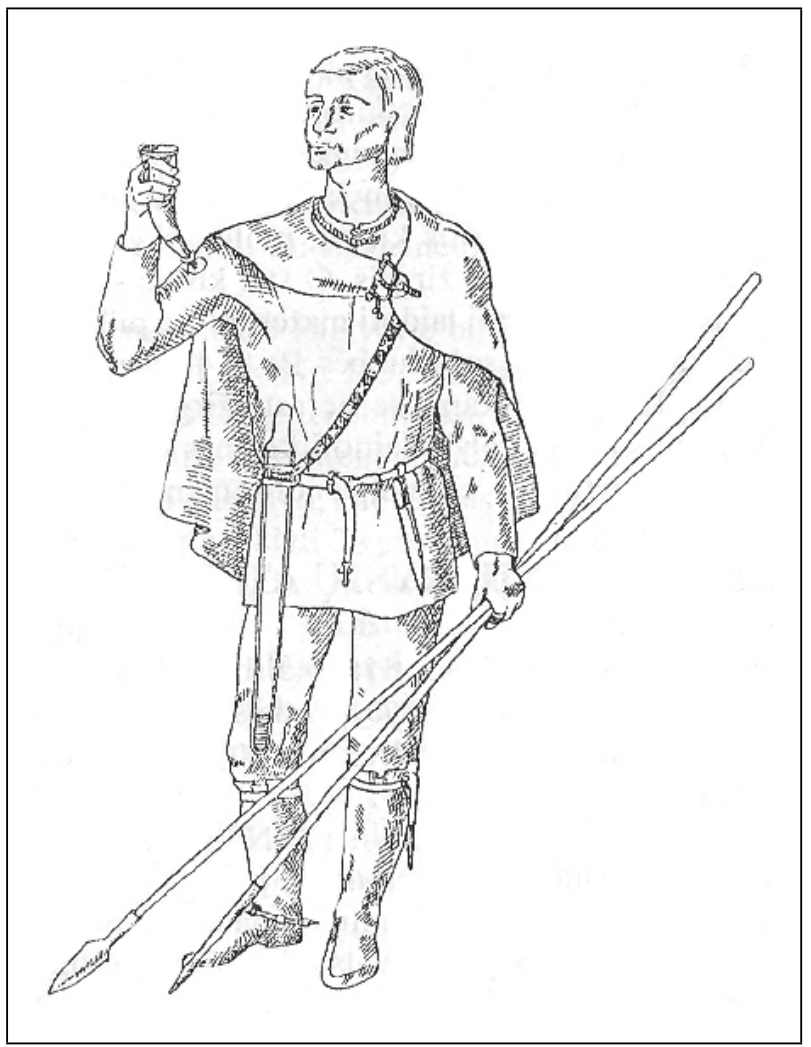

11 pav. Karvedys (remiantis Pagrybio ir Plinkaigalio kapinynų tyrimų duomenimis L. Vaitkunskienès parengta rekonstrukcija) jụ kariaunų iškilimo baltų žemèse etapu hipotezè.

Lieka dar vienas labai svarbus kariaunų raidos klausimas - kada apskritai baltu žemèse galèjo atsirasti kariaunų? E. Jovaiša, analizuodamas Dauglaukio bendruomenès socialinę sanklodą ir gretindamas šios baltiškos bendruomenès ir vienalaikių germanų genčių socialinio ir ekonominio išsivystymo požymius, pasinaudodamas romėnų auto-

90 Кулаков В. И. Пруссы (V-XIII вв.). Москва, 1994, с. 149-152. 
riaus Tacito žiniomis apie to meto germanų žemèse vykusius procesus, prieina prie išvados, kad būta aiškių vieno ir to paties laikotarpio germanų ir baltų visuomenių struktūros ir kultūros lygio bendrumų. Ypač aiškiai tai atsiskleidžia lyginant ginkluotę ${ }^{11}$. Pritarčiau nuomonei, jog kariaunos baltų žemèse galejo formuotis ir egzistuoti jau senajame geležies amžiuje - pirmaisiais amžiais po Kr. čia (pirmiausia vakarinejje baltų arealo dalyje) susiklostè tam palankios socialinès ir ekonominès sąlygos. Nuomonès, kad baltų karinès organizacijos aptariamuoju laikotarpiu buvo artimos atitinkamoms to meto germanų organizacijoms, laikosi ir karybą dabartinès Baltarusijos teritorijoje iki XII a. tiriantis J. Novikovas ${ }^{92}$.

\section{RAITIJOS KLAUSIMAS}

Labai svarbūs baltų karybos raidos tyrimai susiję su raitija. Archeologų bendruomenei be jokių išlygų sutinkant, kad viduriniame geležies amžiuje baltai neabejotinai buvo raiteliai (tai patvirtina nusistovèjęs raitelio reikmenų kompleksas, akivaizdus žirgo kultas baltų dvasiniame gyvenime, žirgų ar jų dalių laidojimo kapinynuose kartu su žmonėmis paprotys), kai kurie istorikai (D. Baronas, A. Nikžentaitis, A. Bumblauskas) teigia, jog dar XIII a. baltai nemokejjo kautis raiti - tik joti, tad žirgas atlikdavo transporto priemonès funkciją ${ }^{93}$.

$\mathrm{Su}$ šia nuostata nesutinku. Remdamasis plačia archeologinių ir rašytinių šaltinių analize esu prièjęs prie išvados, kad vèliausiai I t-mečio pabaigoje-II t-mečio pradžioje Lietuvoje buvo nusistovejęs visas raitelio ir žirgo aprangos kompleksas, leidžiantis raiteliui tvirtai jaustis balne ir tinkamai valdyti žirgą. Jau tada dalị lietuvių karinių pajègų galèjo sudaryti lengvoji

\footnotetext{
91 Jovaiša E. Baltai antikos laikais: Dauglaukio bendruomenės eskizas // Lietuva iki Mindaugo. Vilnius, 2003, p. 163-183.

92 Новікаў Я. Ваенная гісторыя Беларускіх земляў (да канца ХII ст.). Том 1. Мінск, 2007 , c. 63.

93 Baronas D. Lietuvių karyba XIII a. // Karo archyvas. T. XVI. Vilnius, p. 20; Baronas D. Lietuvių karybos bruožai XIII a. pradžioje // Lietuvos valstybė XII-XVIII a. Vilnius, 1997, p. 502; Bumblauskas A. Senosios Lietuvos istorija 1009-1795. Vilnius, 2005, p. 34; Nikžentaitis A. XIII-XV a. lietuvių kariuomenès bruožai (organizacija, taktika, papročiai) // Karo archyvas. T. XIII. Vilnius, 1992, p. 6-10; Nikžentaitis A. Nuo Daumanto iki Gedimino. Ikikrikščioniškos Lietuvos visuomenès bruožai. Klaipėda, 1996, p. 38-39.
} 


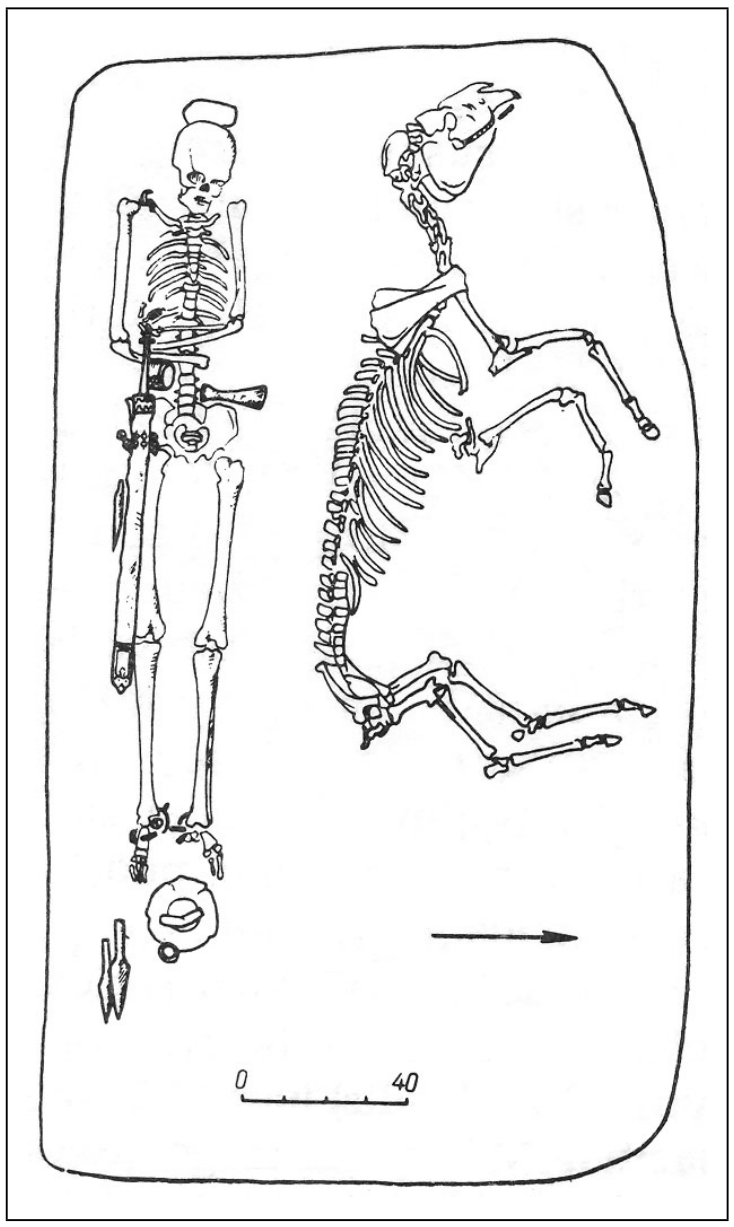

12 pav. „Kunigaikščio“ kapas Taurapilio pilkapyno (Utenos r.) pilkapyje Nr. 5

kavalerija. Rašytiniai šaltiniai patvirtina, kad nuo XIII a. pradžios lietuviai kariai gebejo kautis raiti ir egzistavo lietuvių lengvoji kavalerija ${ }^{94}$.

Rytiniame Baltijos jūros pakraštyje kartu su pirmaisiais indoeuropiečiais maždaug 3000 m. pr. Kr. atsirado ir žirgų. Ženklų, kad tai buvo karys raitelis, pastebima jau I a. po Kr. baltiškoje archeologinèje medžiagoje. Apie $70 \mathrm{~m}$. pradedami daryti žirgui valdyti skirti pentinai, kiek vèliau žąslai. Anot E. Jovaišos ir M. Iršèno, 70-150 m. baltu kraštuose susiformavo raitelio aprangos kompleksas. Ji sudarè: pentinai, žąslai ir kamanos, gūnia ir galbūt balnas ${ }^{95}$. V. Šimènas pirmuosius pentinus mūsų

94 Vitkūnas M. Kada baltai pradèjo kautis raiti? // Lituanistica. Vilnius, 2011, T. 57, Nr. 1 (83), p. 54-65.

95 Iršènas M., Jovaiša E. Kario ir žirgo puošyba priešistorès mene // İdomioji Lietuvos istorija. Meno istorija nuo seniausių laikų iki mūsų dienų. Vilnius, 2006 [kompaktine plokštelè]. 
žemėse datuoja II a. (nurodo vèlesnị amžių) ${ }^{96}$, tačiau nedidelès chronologijos „žirklès“ esmès nekeičia: $\mathfrak{i}$ vidurinị geležies amžių baltai ižzengé turedami beveik visą raitelio reikmenų rinkinį, o netrukus apsirūpino ir balnakilpèmis. Taip pat svarbu pabrežti, kad geležies amžiaus baltų laidojimo papročiuose pabrěžiamas išskirtinis kario raitelio ir žirgo santykis. Beveik visoje Lietuvoje randama raitelių ir žirgų kapų, kurie datuojami II a. - krikščionybės pradžia.

$\mathrm{V}$ a. viduryje perversmą karyboje sukèlè naujas aprangos elementas balno kilpos. Manoma, kad tai - klajoklių alanų ar avarų išradimas. Jị greitai perèmé baltai. Ilgą laiką vyravo nuomonè, kad dabartinèje Lietuvos teritorijoje balnakilpés atsirado $\mathrm{X} \mathrm{a}{ }^{97}$, o balnas - I t-mečio pab.-II t-mečio pr. ${ }^{98}$ Tačiau balnakilpès baltų kraštuose buvo naudojamos kur kas anksčiau. Seniausi balnakilpių prototipai - odos, virvių kilpos, ̣̇vairios medinès konstrukcijos. Su tiurkų gentimis balnakilpés iš Azijos stepių pateko ị Europą ${ }^{99}$. Manoma, kad VI a. balnakilpes ị Europą atsinešè avarai. Bizantijos ir kitų Europos kraštų raiteliai ${ }^{100}$ tikriausiai jas peremé iš Panonijoje ịsikūrusių avarų (veikiausiai - per tarpininkus, o galbūt ir tiesiogiai, nes avarai rengè žygius ir ị šiaurę, link Baltijos pakrančių). Avariškų balnakilpių randama Lenkijos teritorijoje ${ }^{101}$, joms labai artimų tipų balnakilpių rasta ir Marvelès (Kauno miesto dalis) kapinyne. Jos datuojamos VI a. pab.-VII a. Nemažai balnakilpių randama kituose vidurinio

96 Šimènas V. Etnokultūriniai procesai Vakarų Lietuvoje pirmojo mūsų eros tūkstantmečio viduryje. Vilnius, 2006, p. 96.

97 Antanavičius J. Balno kilpos Lietuvoje X-XIV a. TSR mokslų akademijos darbai. A serija. Vilnius, 1976, T. 1, p. 69-81; Kulikauskas P., Kulikauskienė R., Tautavičius A. Lietuvos archeologijos bruožai. Vilnius, 1961, p. 350; Vaitkunskienė L. Balnakilpès // Visuotinè lietuvių enciklopedija. T. II. Vilnius, 2002, p. 508-509; Volkaitè-Kulikauskienè R. Lietuvio kario žirgas. Acta historica Lituanica. T. VII. Vilnius, 1970, p. 18.

98 Kulikauskienė R., Štuikys V. Balnas // Visuotinė lietuvių enciklopedija. T. II. Vilnius, 2002, p. 509; Navickaitė O. Plokštinių kapinynų tyrinejjimai Lietuvoje 1948-1959 m. // Iš lietuvių kultūros istorijos. T. IV. Vilnius, 1961, p. 81.

99 Сагановіч Г. Стрэмя // Археалогія і нумізматыка Беларусі. Энцыклапедыя. Мінск, 1993, с. 592.

100 Тараторин В. Конница на войне: история кавалерии с древнейших времен до эпохи Наполеоновских войн. Минск, 1999, с. 155-156.

${ }^{101}$ Mączyńska M. Wędrówki ludów: historia niespokojnej epoki IV i V wieku. Warszawa, 1996, p. 284. 
ir vèlyvojo geležies amžiaus Vidurio Lietuvos kapinynuose ir kitų baltų genčių laidojimo paminkluose. Itin archajiškų, vienų seniausių Europoje, VII a. datuojamų balnakilpių rasta ir Prūsijoje. Atkreipkime dèmesi balnakilpès baltų žemėse pradètos naudoti visu šimtmečiu anksčiau nei Vakarų Europoje ${ }^{102}$. Apskritai archeologiškai fiksuoti baltų ryšiai su puikiais raiteliais hunais $\mathrm{V}$ a. ir avarais VI-VII a. neabejotinai turèjo įtakos sparčiai baltų raitijos raidai.

Manoma, kad iš baltų balnakilpes perèmė skandinavai. Skandinaviškos balnakilpès galèjo būti prūsiškos ar aukštaitiškos (iš Vidurio Lietuvos) kilmès. Beje, Skandinavijoje randama ir kitų iš baltų žemių atkeliavusių žirgo aprangos elementų, pavyzdžiui, puošnių baltiškos kilmès kama$n u^{103}$. Žirgais baltai dažnai jodinèjo, ir Europos mastu buvo ne atsiliekantys, o veikiausiai netgi vieni iš pirmaujančiųjų. Jiems teko jojimo reikmenų ir jų gamybos technologijų skleidejų plačiame Šiaurès Rytų Europos regione vaidmuo. Baltarusijos istorikas J. Novikovas, parengęs išsamią

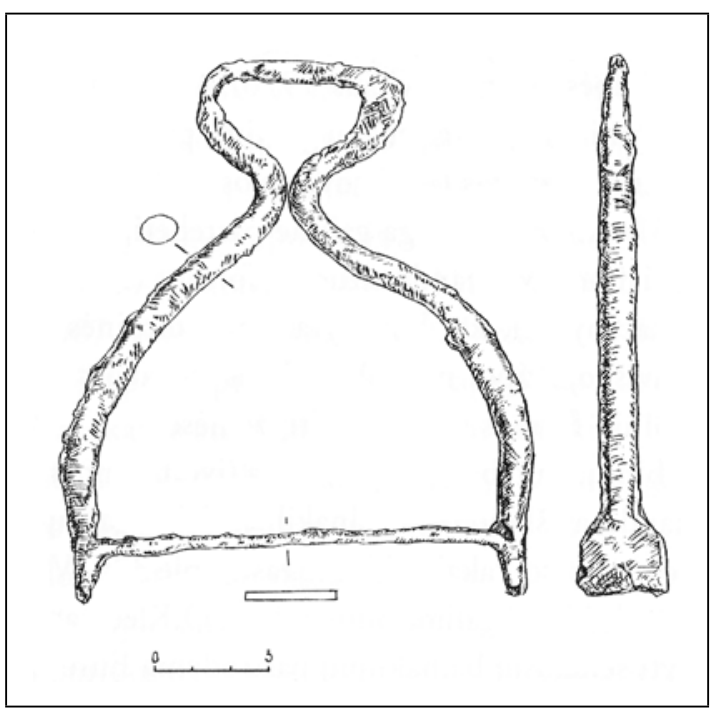

13 pav. Balnakilpè iš Marvelès (Kauno m.)

kapinyno kapo Nr. 45 studiją apie karybą dabartinès Baltarusijos teritorijoje iki XII a., netgi kelia hipotezę, kad baltai turèjo geriau išvystytą raitiją nei slavai. Šią prielaidą jis kelia atsižvelgdamas ì tai, kad plačiame baltų areale išskirtinai dažnai pasitaiko turtingu su žirgais palaidotų karių kapų. J. Novikovas linkęs atsargiai vertinti V-IX a. slavų raitijos pajègumą ir mano, kad žirgas sla-

\footnotetext{
${ }^{102}$ Bertašius M. Vidurio Lietuva VIII-XII a. Kaunas, 2002, p. 193-195.

${ }^{103}$ Ten pat, p. 194.
} 
vams pirmiausia buvo transporto priemonè, leidžianti įveikti didelius atstumus. Tokią prielaidą jis daro remdamasis kelių Bizantijos autorių žinutemis apie tai, kad mūšio pradžioje slavų kariai nulipa nuo žirgų ${ }^{104}$. Kiti autoriai, pvz., žymus Rusijos karo istorijos specialistas V. Taratorinas, laikosi priešingos nuomonès ir teigia, kad slavai turèjo kavaleriją, panašaus pajègumo ir panašiai naudojamą kaip ir germanų ${ }^{105}$.

Taigi aiškiai matome, kad I t-mečio viduryje ir antroje jo pusejje baltų žemèse susiformavo visas raitelio ir žirgo reikmenų kompleksas. Baltai neabejotinai mokejo gerai joti ir turejo tam visas reikalingas priemones. Puikiai joti ir valdyti žirgus jie tikrai gebejjo. Bet ar kovèsi raiti? Kaip jau minèjau, esu tikras, kad lengvoji lietuvių kavalerija egzistavo I ir II t-mečio sandūroje, o XIII a. rašytiniai šaltiniai tai patvirtina. Ar galèjo baltų kavalerija gyvuoti ir anksčiau? Esu tikras, kad taip. Šio laikotarpio rašytinių šaltinių nèra, tačiau tai, kad baltai turejo žirgų ir raitelio reikmenų, sudarė visas prielaidas lengvajai kavalerijai atsirasti. Kautis raiti mokejo baltų kaimynai, su kuriais intensyviai kontaktuota, - germanai, veikiausiai ir slavai. Sunku patikèti, kad tame pačiame regione panašiomis gamtinèmis sąlygomis gyvenę ir visą reikiamą raitelio reikmenų kompleksą turèję baltai būtų buvę vien pèstininkai arba žirgais jodinèjantys „raitieji péstininkai“, t. y. juos naudojantys tik persikelti iš vienos vietos ị kitą, bet nemokantys kautis raiti.

\section{STRATEGIJA IR TAKTIKA}

Sunkiausiai rekonstruojamas praeities epochų karybos aspektas (ypač kai turima labai mažai arba išvis neturima rašytinių šaltinių) - taktika. Kai nèra mūšių aprašymų, tenka remtis archeologiniais radiniais, ginkluotès kompleksais ir bandyti interpretuoti jų egzistavimo ir naudojimo sąlygas žvelgiant per karybos istorijos prizmę. Tam tenka pasitelkti ir rašytinius šaltinius apie panašaus ekonominio ir socialinio išsivystymo lygio kaimyninių bendruomenių, gyvenusių panašioje gamtinèje aplinkoje

${ }^{104}$ Новікаў Я. Ваенная гісторыя Беларускіх земляў (да канца XII ст.). Том 1. Мінск, 2007, с. 73-74.

105 Тараторин В. Конница на войне: история кавалерии с древнейших времен до эпохи Наполеоновских войн. Минск, 1999, с. 153-154. 
ir naudojusių panašią ginkluotę, karybą.

Pradedant nagrinèti baltų karių taktiką aptariamuoju laikotarpiu pirmiausia reikia išsiaiškinti, kokius strateginius uždavinius galejo kelti baltų genčių didžiūnai, kariaunų vadai savo kariams. Dažniausiai tai buvo plěšiamieji žygiai ị kaimyninių ir tolimų (svetimų) bendruomenių, genčių teritorijas. Tokie žygiai turèjo būti trumpi, jais nesiekta ilgalaikių tikslų (užimti priešo teritoriją, ịsitvirtinti joje). Tam reikejjo turèti gerai parengtas, judrias (pageidautina - raitelių), tačiau nebūtinai gausias pajègas. Pagrindinis plèšiamojo žygio sèkmę lemiantis veiksnys - netikètumas, svarbiausias tikslas - grobis ir sèkmingas atsitraukimas, patyrus kuo mažiau nuostolių.

Visiškai priešingas strateginis uždavinys buvo savo žemių gynyba nuo galimų priešo antpuolių. Jos ginti turèjo stoti visi, pajègūs rankose laikyti ginklą. Galimybès apsiginti nuo priešo puolimo dažnai priklausė nuo konkrečios situacijos, laiku gauto perspejjimo apie pavojų ir gebejjimo organizuoti gynybą. Archeologinių tyrimų duomenys kartais atskleidžia dramatiškus praeities kovų puslapius, liudijančius, kad priešo ịsiveržimas buvo itin staigus ir netikètas. Bene iškalbingiausias pavyzdys - Plinkaigalio kapinyne (Kèdainių r.) rastas priešo (veikiausiai klajoklių hunų) antpuolio metu išžudytos šeimos grupinis kapas. Jame rasti trisparniai strèlių antgaliai ir aukų kauluose išlikę smurtinių sužalojimų pėdsakai liudija, jog per antpuoli bėgantys nuo užpuolikų žmonès (keli suaugusieji ir vaikai) buvo apšaudyti strèlemis: viena jų, perskrodusi pilvą, ìsmigo vyrui ị stuburą, kita - moteriai ị koją. Pavytas aukas užpuolikai užmušè kirviais arba vėzdais ${ }^{106}$. Akivaizdu, kad Plinkaigalyje gyvenusios bendruomenės žmonès nesitikèjo užpuolimo, nebuvo įspèti apie besiartinantị priešą arba tai buvo padaryta per vèlai.

Antra vertus, neturime pagrindo abejoti, jog išankstinę informaciją apie rengiamą priešo antpuolị gavusios bendruomenès sugebėdavo pasitraukti i piliakalniuose buvusius ịtvirtinimus ir pasirengti gynybai arba bent jau atsitraukti ị priešui sunkiau prieinamas miškingas, pelkètas vietoves. Palankiomis aplinkybėmis kariai galejjo surengti artèjančiam priešui pasalą.

${ }^{106}$ Kazakevičius V. Plinkaigalio kapinynas. Lietuvos archeologija. T. 10. Vilnius, 1993, p. 35-39. 
Trečio tipo strateginis uždavinys turèjo būti teritorinè ekspansija. Baltų gentys ją vykdė ribotai. Akivaizdus aptariamuoju laikotarpiu vykęs tam tikras genčių gyvenamų teritorijų ribų kitimas ir naujų ỉsisavinimas (pvz., prūsų teritorinè plètra nuo Sembos pusiasalio ir Priegliaus upés baseino i̇ Vyslos žemupi). Teritorinè ekspansija buvo veikiausiai ne atskirų bendruomenių, o ištisų genčių, daugelio didžiūnų aptariamas ir gausiomis pajègomis igyvendinamas procesas (nebent plètra ekstensyviai būtų vykusi ị niekieno nekontroliuojamą neužimtą teritoriją). Tačiau akivaizdu, jog viduriniame geležies amžiuje baltai ne tiek patys vykdè teritorinę ekspansiją, kiek turejo nuo jos gintis - jų pačių teritorija tapo svetimų kultūrų ekspansijos objektu. Tai ypač tinka kalbant apie rytinę baltų arealo dalį. Baltiškų Moščino, Koločino, Tušemlios-Bancerovo kultūrų areale nemažai archeologinių tyrimų metu rastų gaisrų, sugriovimų pẻdsakų sietini būtent su intensyviai vykusia slavų ekspansija ị baltų žemes, nors kai kuriuose archeologijos paminkluose randama ir taikaus kultūros perèmimo pèdsakų ${ }^{107}$.

Neabejotinai buvo rengiama ir kitų tipų karo žygių, pvz., siekiant atkeršyti konkrečiam asmeniui ar asmenu grupei. Manyčiau, jog ir prekybiniai kontaktai (to meto prekijus kelionèse lydejo ginkluota palyda), susiklosčius nepalankiai situacijai, lengvai galejo virsti kariniu susidūrimu.

Kokia galèjo būti baltų taktika aptariamuoju laikotarpiu? Pirmiausia svarbu išsiaiškinti, ar kariai kaudavosi kovos rikiuote, ar kautynės vykdavo padrikai. Manau, kalbėti apie tuo metu galejusią egzistuoti nusistovèjusią taisyklingą kovos rikiuotę būtų išties nepagrịsta, galima tik spèti buvus jos užuomazgų. Rusijos istorikas A. Nefiodkinas, remdamasis VI a. Bizantijos rašytiniais šaltiniais, teigia, kad slavų kariai nebuvo rikiuojami taisyklinga kovos rikiuote. Jie mūšio lauke buvo grupuojami teritoriniu arba giminystès principu (vienos bendruomenès, giminès ar šeimos kariai sudarydavo savo padalinị). Tokiuose būriuose kariai buvo ginkluoti ¿̇vairia ginkluote - tai priklausė nuo galimybių ir poreikio. Kautynėms vykstant atvirame lauke kariai link priešo iš pradžių artėdavo kolonomis, vẻliau persirikiuodavo ị gana vingiuotą, netvarkingą rikiuotę. Jos priekyje buvo statomi skydais ginkluoti kariai. Jie pridengdavo iečių svaidytojus

${ }^{107}$ Vitkūnas M. Baltų karyba viduriniame ir vèlyvajame geležies amžiuje. Dniepro baltai // Karo archyvas. T. XXIV. Vilnius, 2009, p. 4-34. 
ir lankininkus. Kai kovojančios pusès priartėdavo viena prie kitos, prasidèdavo artimoji kova. Jei priešas neišlaikydavo puolančiųjų spaudimo, buvo švenčiama pergalè. Jei priešas atlaikydavo spaudimą - traukiama$\mathrm{si}^{108}$. Tokia "pusiau reguliari“ kovos rikiuote galèjo veikti atviroje vietoje. Miške ar labai raižytoje (dèl raguvų ir pan.) vietoveje, taip pat pakliuvus i pasalą arba puolant iš pasalų tekdavo kautis padrikai.

Baltų raitelių taktika veikiausiai buvo panaši ị germanų. Raitija buvo pagrindinė jèga tolimesniuose karo žygiuose ir svarbi sudedamoji karinių pajėgų dalis (greta péstininkų) gynybinèse kovose arba vietiniuose kariniuose konfliktuose, vykstančiuose nedidelejje teritorijoje. Raitijai teko judriosios žvalgybos, ryšių palaikymo funkcijos, tačiau mūšyje svarbiausi jos uždaviniai veikiausia buvo priešo pajègų suskaldymas, jų apejjimas iš šono ir apsupimas, kad galima būtų suduoti smūgi iš užnugario. Tai klasikinès kavalerijos užduotys, žinomos ịvairaus ekonominio ir socialinio išsivystymo lygio ir įvairiomis sąlygomis gyvenusioms antikos ir ankstyvųjų viduramžių Europos visuomenèms. Minėtiems veiksmams atlikti nereikia darnios raitelių kovos rikiuotès, kurios baltai veikiausia dar nebuvo įvaldę. Kovoje su panašiai organizuotomis, nežinančiomis, kas yra taisyklinga kovos rikiuotè, priešo pajègomis pakanka išnaudoti individualų raitelių pranašumą (greití, manevringumą, pralaužiamąją galią).

Manau, kad baltų, kaip ir daugelio germanų genčių (išskyrus patyrusias tiesioginę Romos ịtaką ir perèmusias dalį antikinio pasaulio karybos patirties), raiteliai nemokejo kautis taisyklinga kovos rikiuote. Bizantijos ir kitų kraštų autoriai pažymi, kad germanų kariai nemokèjo kautis tvarkingai, tačiau buvo itin drąsūs, bet kokị atsitraukimą laikè nenuplaunama gèda. V a. galų kilmès autorius Sidonijus Apolinarijus gana išsamiai aprašo Merovingų laikų germanų mišriaja raitelių ir péstininkų taktiką: „Raitija mūšyje veikdavo kartu su lengvaisiais pėstininkais. Dažniausiai kiekvienas raitelis išsirikdavo sau bendražygi pėstininką, ir jie įsipareigodavo vienas kitą ginti ir vienas kitam padèti. Mūšyje pėstininkai iš pradžių išnaudodavo savo svaidomąją ginkluotę, po to, kai ì puolimą mesdavosi raiteliai, pėstininkai sekdavo iš paskos, kad pultų j kovą su priešo kariais, žalotų jų arklius. Jei ataka nepavykdavo, pèstininkai dengdavo

${ }^{108}$ Нефёдкин А. Тактика славян в VI в. (по свидетельствам ранневизантийских авторов) // Византийский временник. Т. 62 (87). Москва, 2003, с. 87-90. 
atsitraukimą. Prireikus jie sėsdavo ant arklių. Jei vietovė buvo palankesnè kautynèms pésčiomis, germanai nulipdavo nuo žirgų ir juos palikdavo, nes šie buvo išmokyti laukti vietoje. “109

Aprašytoji taktika visiškai galejo tikti ir baltams. Manau, jog gana atviroje vietoveje baltai kaudavosi ir pèsti, ir raiti, jei mūšis vyko labai raižytoje vietoveje arba miške - pèsti.

Aptariamuoju laikotarpiu pajūryje gyvenusios baltų gentys, be abejo, vertèsi ir laivyba, vyko tam tikro masto baltų kovos jūroje. Tačiau apie jüru kovos taktika pasakyti ką nors daugiau kol kas negalime. Baltu žemèse nerasta nè vieno vidurinio geležies amžiaus jūrų laivo likučių. Svarstyti apie baltų jūrų laivybą V-VIII a. kol kas galime tik teoriškai, remdamiesi vienalaikių laivybos artefaktų, rastų vakarinèje ir pietinejje Baltijos jūros pakrantèse, tyrimais. Vidaus vandenyse kariams ir ginklams gabenti neabejotinai galèjo būti naudojami luotai.

\section{BAIGIAMOSIOS IŠVADOS}

1. Geriausiai ištirta vidurinio geležies amžiaus baltų karybos sritis ginkluotė. V. Kazakevičius ir kiti tyrèjai yra sudarę gana išsamią ginklų tipologijos sistemą. Tačiau iki šiol padarytos išvados apie atskirų tipų ginklų santykị baltų karyboje yra tikslintinos. Nekvestionuojant ieties, kaip plačiausiai baltų naudoto ginklo, įvairių tipų kalavijų, skydų vertinimo, galima teigti, kad nepagrịstai buvo sumenkinta kirvių ir peilių reikšmé baltų ginkluotès kompleksuose.

2. Dažniausiai baltų kario ginkluotès kompleksą viduriniame geležies amžiuje sudarè ietis, kirvis ir peilis. Aukštesnio socialinio statuso karių ginkluotèje buvo ir vienašmenis arba (labai retai) dviašmenis kalavijas. Pagrindinis apsauginès ginkluotès atributas skydas nebuvo masiškai naudojamas - skydus turejjo tik dalis karių.

3. Ginkluotè buvo skirta tolimajai ir artimajai kovai. Mūšio pradžioje, priartèjus tinkamu atstumu iki priešo, buvo sviedžiamos ietys, po to puolama tiesiogiai kautis su priešu kirviu (kalaviju arba smogiamąja ietimi). Peilis buvo naudojamas savigynai arba priešui pribaigti. Lankas baltų že-

109 Тараторин В. Конница на войне: история кавалерии с древнейших времен до эпохи Наполеоновских войн. Минск, 1999, с. 149. 
mėse, atrodo, vaidino nepagrindinị vaidmenị.

4. I t-mečio viduryje ir antrojoje pusèje baltų žemèse buvo naudojamas visas raitelio ir žirgo reikmenų kompleksas: pentinai, žąslai, kamanos, balnakilpès, gūnia ir galbūt balnas. Buvo visos prielaidos lengvajai kavalerijai atsirasti.

5. Baltų karinèse pajègose būta ir pėstininkų, ir raitelių, kurie gebejjo kautis atskirai arba išsidèstę rikiuote. Puolamuosiuose žygiuose galejo dalyvauti ir vien raiteliai. Nepalankiomis sąlygomis kovoti raitomis (miške, raižytoje vietoveje) raiteliai nulipdavo nuo žirgų ir kaudavosi pėsti.

6. Baltų žemėse viduriniame geležies amžiuje buvo susiformavusių kariaunų, pavaldžių atskirų bendruomenių ir galbūt genčių didžiūnams.

Iteikta $2011 \mathrm{~m}$. lapkričio $21 \mathrm{~d}$. 


\section{ILIUSTRACIJŲ ŠALTINIAI}

1 pav. Ornamentuotas kirvis iš Neravų (Grigiškių) pilkapyno. Iš: Malonaitis A. Geležiniai siauraašmeniai kirviai Lietuvoje. Vilnius: Vilniaus pedagoginio universiteto leidykla, 2008, p. 162, 23 pav.

2 pav. Popų-Vingelių pilkapyne (Elektrènų sav.), pilkapyje Nr. 2, kape Nr. 1, rastos kario ịkapès: sagtis, du ietigaliai, kirvis ir skydo umbas. Iš: Kernavè - litewska Troja (Katalog wystawy ze zbiorow Państwowego Muzeum - Rezerwatu Archeologii i Historii w Kernave, Litwa). Warszawa: Państwowe Muzeum Archeologicne, 2002, s. 121.

3 pav. Kovos peiliai-durklai iš Vidgirių kapinyno (Pagègių sav.). Iš: Šimẻnas V. Etnokultūriniai procesai Vakarų Lietuvoje pirmojo mūsų eros tūkstantmečio viduryje. Vilnius: Vilniaus universiteto leidykla, 2006, p. 56,26 pav.

4 pav. Perpetè ir jos nešiojimo būdo rekonstrukcija, remiantis Vidgirių kapinyno (Pagėgių sav.) tyrimų duomenimis. Iš: Šimẻnas V. Etnokultūriniai procesai Vakarų Lietuvoje pirmojo mūsų eros tūkstantmečio viduryje. Vilnius: Vilniaus universiteto leidykla, 2006, p. 57, 27 pav.

5-6 pav. Dviašmenis kalavijas ir sidabrinès paauksuotos kalavijo makščiu apkalos iš Taurapilio pilkapyno (Utenos r.) pilkapio Nr. 5. Iš: Tautavičius A. Vidurinis geležies amžius Lietuvoje (V-IX a.). Vilnius: Pilių tyrimo centras „Lietuvos pilys“, 1996, p. 141, 50-51 pav.

7-8 pav. Vienašmenis kalavijas, rastas Pagrybio kapinyno (Šilalès r.) kape Nr. 10, ir pagal kapų Nr. 10 ir Nr. 158 radinius rekonstruotos kalavijo makštys. Iš: Vaitkunskienė L. Pagrybio kapinynas. Lietuvos archeologija. T. 13. Vilnius: Diemedis, 1995, p. 107, 150, 152 pav.

9 pav. Platusis kovos peilis - kalavijas, grandelès ir ietigaliai, rasti Šukionių kapinyno (Pakruojo r.) kape Nr. 13. Iš: Vaškevičiūtė I. Šukionių kapinynas // Lietuvos archeologija. T. 20. Vilnius: Diemedis, 2000, p. 171, 24 pav. 
10 pav. Antskydis (skydo umbas) iš Krikštoniu (Lazdijų r.). Iš: Tautavičius A. Vidurinis geležies amžius Lietuvoje (V-IX a.). Vilnius: Pilių tyrimo centras „Lietuvos pilys“, 1996, p. 148, 54 pav.

11 pav. Karvedys (remiantis Pagrybio ir Plinkaigalio kapinynų tyrimų duomenimis L. Vaitkunskienès parengta rekonstrukcija). Iš: Vaitkunskienė L. Pagrybio kapinynas. Lietuvos archeologija. T. 13. Vilnius: Diemedis, 1995, p. 165, 226 pav.

12 pav. „Kunigaikščio“ kapas Taurapilio pilkapyno (Utenos r.) pilkapyje Nr. 5. Iš: Tautavičius A. Taurapilio „kunigaikščio“ kapas // Lietuvos archeologija. T. 2. Vilnius: Mokslas, 1981, p. 21, 5 pav.

13 pav. Balnakilpè iš Marvelès (Kauno m.) kapinyno kapo Nr. 45. Iš: Bertašius M. Vidurio Lietuva VIII-XII a. Kaunas: Vytauto Didžiojo universitetas, 2002, p. 193, 90-I pav. 


\title{
CARACTÉRISTIQUES DES ACTIONS MILTAIRES DES BALTES DANS LE MOYEN SIÈCLE DE FER (V-VIII SIÈCLE)
}

\author{
Dr. Manvydas Vitkūnas, \\ Académie de guerre du Général Jonas Žemaitis de Lituanie
}

Cette article śagit des caractéristiques des actions militaires des baltes (à l'exclusion des baltes de Dniepr) dans le moyen siècle de fer - V-VIII siècle (lors de la période du déménagement des peuples) : l'armement, le problème de l'utilisation des chevaux (la formation de la cavalerie), le développement de l'organisation militaire ainsi que la tactique de la bataille.

L'information des recherches archéologiques est extrêmement utile afin de connaître les actions militaires des baltes lors de la période discutée pendant que les sources écrites concernant les baltes dans la période du V-VIII siècle sont très fragmentaires. Pour cette raison l'article est appuyé premièrement sur les données des recherches archéologiques.

Domaine qui est analysé le mieux dans le moyen siècle de fer concernant les actions militaires des baltes - c'est l'armement. V. Kazakevičius avec les autres chercheurs sont établis une typologie des armes assez détaillée. Toutefois, les conclusions prises jusqu'ici concernant la relation des armes du différent type dans les actions militaires devraient être corrigées encore.

Une lance était une arme utilisée le plus fréquemment par les baltes sans doute ainsi que les autres armes tels que des sabres divers et des boucliers, mais il est possible d'affirmer que le rôle des haches et des couteaux dans les complexes d'armement des baltes était gratuitement rabaissé.

Le plus fréquent complexe d'armement du soldat des baltes dans le moyen siècle de fer était composé d'une lance, d'une hache et d'un couteau. Pendant que l'armement du soldat de plus haute statut social il y avait un sabre d'une lame ou (très rarement) des deux lames. L'attribut principal de l’armement sécurisé était le bouclier, mais il nétait utilisé que pour une partie des soldats. 
Armement avait pour le but la bataille à distance ainsi que la bataille de contact. Au début du combat des lances étaient dardées après avoir approché vers une distance favorable aux ennemis, ensuite ils étaient attaqués en contact direct en utilisant les haches (ou les sabres, ou les lances de choc). Le couteau était utilisé pour l'autodéfense ou en accablent son ennemi pendant que le rôle de l'arc était secondaire.

Au milieu de premier millénaire - en son deuxième moitié les baltes utilisaient toute la complexe des attirails du cavalier et de cheval - c'est-àdire des éperons, le mors, les arçons, la couverture de cheval et peut-être la selle. Il y avait donc toutes les suppositions à retrouver une cavalerie légère.

La force armée des baltes avait aussi des infanteries et des cavaliers qui pourraient combattre séparément ou en rang général. Lors des marches offensives il pourrait être utilisé seulement des cavaliers. En présence des désavantages à combattre dans la position montée (dans la forêt ou dans la place déchirée), les cavaliers descendaient les chevaux et combattaient à pied.

Au moyen siècle de fer dans les terrestres baltes il sétait établi une armée subordonnée aux supérieurs des communes particulières et, peut-être, aux supérieurs des peuplades. Nous sommes capables donc de discuter le sujet de larmée dans les terrestres baltes du début de moyen siècle de fer sans aucunes clauses. Les tombes du V-VI siècles de Pagrybis, Taurapilis et d'autres monuments d’enterrement mentionnées appartenaient indubitablement à lélite militaire distinguée lors de cette période de temps. Cependant quafin de sexpliquer la dynamique du développement des armées, particulièrement dans la deuxième moitié du moyen siècle de fer, il faudrait faire une analyse détaillée des renseignements concernant les monuments d'enterrement. 


\title{
FEATURES OF THE WARFARE OF THE BALTIC TRIBES IN THE MIDDLE IRON AGE (THE V-VIII CENTURIES)
}

\author{
Dr. Manvydas Vitkūnas, \\ The General Jonas Zemaitis Military Academy of Lithuania
}

This paper deals with features of the warfare of the Baltic tribes (except for the Dnieper Balts) in the V-VIII centuries - in the Middle Iron Age (or the Migration Period): weaponry, problem of horse usage (cavalry formation), development of military organization and combat tactics.

To understand the warfare of the Baltic tribes, material of archaeological research provides plenty of information, meanwhile the written sources about the Balts in the V-VIII centuries are highly fragmentary. Therefore this paper is based primarily on the archaeological studies.

Weaponry is the best studied area of the warfare of the Baltic tribes in the Middle Iron Age. V. Kazakevičius and other researchers have composed a sufficiently detailed typology of weapons. However, current conclusions on the relations of individual types of weapons in the warfare of the Baltic tribes need correction. Without denying the importance of spear as a weapon widely used by the Baltic tribes, and the evaluation of various types of swords and shields, it can be stated that the role of axes and knives in the complexes of the weaponry of the Baltic tribes was unreasonably diminished.

The most common weaponry complex of the Baltic warrior in the Middle Iron Age consisted of a spear, an axe and a knife. A single-edged sword or (very rarely) a double-edged sword was in the weaponry of warriors of higher social status. The main attribute of protective weaponry a shield was not massively spread and was used only by some warriors.

The weaponry was designed for remote and contact fight. At the beginning of a battle, when enemy was approached within a reasonable distance, spears were thrown, and then the enemy was attacked in the direct contact, using an axe (or a sword, or a striking spear). The knife was used in self-defence or to kill the enemy. In the Baltic lands, the role of a sho- 
oting bow seems to have been a secondary one.

In the middle of the first millennium and in its second half, full complex of the outfit of a rider and a horse consisting of spurs, a bit, a bridle, stirrups, a rug and perhaps a saddle, was used in the Baltic lands. There were all preconditions for the light cavalry to appear.

In the Baltic military forces, there were both infantry and cavalry, who were able to fight alone or in a battle array. In the offensive campaigns, only the cavalry might have been used. Under the adverse conditions for fighting astride (forest, rugged terrain), riders descended from horses and fought on foot.

In the Baltic lands in the Middle Iron Age the soldiery was formed, which was subject to individual communities, and, perhaps, to the tribal grandees. It is possible to talk about the soldiery in the Baltic lands since the beginning of the Middle Iron Age without any reservation. The mentioned graves of the V-VI centuries from Pagrybys, Taurapilis and other burial monuments undoubtedly belonged to the military elite, which was clearly defined at that time. However, to trace the dynamics of the evolution of the soldieries in later centuries, in particular - in the second half of the Middle Iron Age, can only be possible through detailed analysis of the burial materials. 